ALAN RAFAEL FACHINI

Avaliação de métodos de inferência de Redes de Regulação Gênica 

ALAN RAFAEL FACHINI

\section{Avaliação de métodos de inferência de Redes de Regulação Gênica}

Dissertação apresentada à Escola Politécnica da Universidade de São Paulo para obtenção do título de Mestre em Ciências.

Área de Concentração:

Engenharia de Computação

Orientadora: Anna Helena Reali Costa Co-orientador: David Corrêa Martins Junior

São Paulo

2016 
Este exemplar foi revisado e corrigido em relação à versão original, sob responsabilidade única do autor e com a anuência de seu orientador.

São Paulo, de de

Assinatura do autor:

Assinatura do orientador:

Catalogação-na-publicação

Fachini, Alan Rafael

Avaliação de métodos de inferência de Redes de Regulação Gênica / A.

R. Fachini -- versão corr. -- São Paulo, 2016.

$77 \mathrm{p}$.

Dissertação (Mestrado) - Escola Politécnica da Universidade de São Paulo. Departamento de Engenharia de Computação e Sistemas Digitais.

1.Bioinformática 2.Redes de Regulação Gênica 3.Inferência de Redes 4.Aprendizado de Máquina 5.Comitês de Especialistas I.Universidade de São Paulo. Escola Politécnica. Departamento de Engenharia de Computação e Sistemas Digitais II.t. 


\section{AGRADECIMENTOS}

Agradeço primeiramente à professora orientadora Anna Helena Reali Costa por me encorajar, acreditar neste trabalho e pelo seu compromisso com o rigor científico. Agradeço também ao professor David Corrêa Martins Junior por toda a ajuda neste caminho. Agradeço aos meus pais, Salete e Nivaldo, que sempre me incentivaram e acreditaram no meu trabalho. À Fernanda, por todo o seu carinho e companheirismo.

Gostaria também de agradecer aos amigos que fiz no Departamento de Engenharia de Computação e Sistemas Digitais pelo compartilhamento de conhecimento e discussões inspiradoras. Todos os membros do LTI (Laboratório de Técnicas Inteligentes USP) por todas as discussões e por estarem sempre disponíveis para auxiliarem na minha pesquisa. 

"If you believe too much you'll never notice the flaws; if you doubt too much you won't get started." - R. Hamming, You and Your Research 



\section{RESUMO}

A representação do Sistema de Regulação Gênica por meio de uma Rede de Regulação Gênica (GRN) pode facilitar a compreensão dos processos biológicos no nível molecular, auxiliando no entendimento do comportamento dos genes, a descoberta da causa de doenças e o desenvolvimento de novas drogas. Através das GRNs pode-se avaliar quais genes estão ativos e quais são suas influências no sistema. Nos últimos anos, vários métodos computacionais foram desenvolvidos para realizar a inferência de redes a partir de dados de expressão gênica. Esta pesquisa apresenta uma análise comparativa de métodos de inferência de GRNs, realizando uma revisão do modelo experimental descrito na literatura atual aplicados a conjuntos de dados contendo poucas amostras. Apresenta também o uso comitês de especialistas (ensemble) para agregar o resultado dos métodos a fim de melhorar a qualidade da inferência. Como resultado obteve-se que o uso de poucas amostras de dados (abaixo de 50) não fornecem resultados interessantes para a inferência de redes. Demonstrou-se também que o uso de comitês de especialistas melhoram os resultados de inferência. Os resultados desta pesquisa podem auxiliar em pesquisas futuras baseadas em GRNs.

Palavras-chaves: Bioinformática, Redes de Regulação Gênica, Inferência de Redes, Aprendizado de Máquina, Comitês de Especialistas. 



\begin{abstract}
The representation of the gene regulation system by means of a Gene Regulatory Network (GRN) can help the understanding of biological processes at the molecular level, elucidating the behavior of genes and leading to the discovery of disease causes and the development of new drugs. GRNs allow to evaluate which genes are active and how they influence the system. In recent years, many computational methods have been developed for networks inference from gene expression data. This study presents a comparative analysis of GRN inference methods, reviewing the experimental modeling present in the state-of-art scientific publications applied to datasets with small data samples. The use of ensembles was proposed to improve the quality of the network inference. As results, we show that the use of small data samples (less than 50 samples) do not show a good result in the network inference problem. We also show that the use of ensemble improve the network inference.
\end{abstract}

Keywords: Bioinformatics, Gene Regulatory Networks, Network Inference, Machine Learning, Ensemble. 



\section{LISTA DE ILUSTRAÇÕES}

Figura 1 - Estrutura do DNA. (a) Nucleotídeos, constituídos de açúcar, fosfato e uma base. (b) As duas fitas formando uma dupla-hélice evidenciando o emparelhamento entre as bases complementares. Adaptado de Alberts et al. $(2010$, p. 3). . . . . . . . . . . . . . . . . . . . . 27

Figura 2 - Expressão Gênica. Adaptado de Gardner e Faith (2005). . . . . . . 29

Figura 3 - Representação do RNA Polimerase, processo pelo qual se dá a transcrição dos genes. Adaptado de Alberts et al.[2010, p. 436). . . 30

Figura 4 - Recorte de um sistema de regulação gênica. Genes são transcritos em RNA que são traduzidos em proteínas que nesse exemplo agem como fatores de transcrição de outros genes. O Gene1 atua na expressão do Gene2 e Gene3. Adaptado de Hecker, Lambeck e Toepfer (2009). . . . . . . . . . . . . . . . . . . 33

Figura 5 - Representações de uma GRN, (a) matriz de adjacência, (b) grafo e (c) lista de adjacência. Adaptado de Hache $[2009$, p. 11). . . . . . . 33

Figura 6 - Redes livres de escala são caracterizadas por uma distribuição de lei de potência, $P(k)=k^{-\mathcal{Y}}$, onde $k$ é o grau médio de cada vértice do grafo, e $P(k)$ a probabilidade. . . . . . . . . . . . . . 34

Figura 7 - Uma rede livre de escala e seus hubs (vértices cinzas e com maior grau que os outros). . . . . . . . . . . . . . . . . 35

Figura 8 - Framework utilizado pelo método WGCNA. . . . . . . . . . . . 41

Figura 9 - Os quatro níveis de informação dos parâmetros regulatórios que podem ser determinados por técnicas de inferência de rede. Os métodos tratam da questão regulatória em um dos níveis ou de níveis combinados. Adaptado de (LIU, 2015). . . . . . . . . . . . . . . 44

Figura 10-Geralmente não se conhece a estrutura da rede de um sistema regulatório real, impedindo a avaliação dos métodos aplicados para sua inferência. Adaptado de Marbach et al.[(2009). . . . . . . . . . . 47

Figura 11 - Diagrama descrevendo as fases da análise computacional e avaliação de métodos de inferência de GRNs. Dado um Padrão Ouro, dados de expressão gênica são gerados, os quais são utilizados por diferentes métodos de inferência, gerando GRNs, os quais são comparados e avaliados com relação ao Padrão Ouro. . . . . . . . . . . . . . . 48 
Figura 12 - Comparação entre o Padrão Ouro (a) e uma GRN inferida (b) e suas respectivas matrizes de adjacência. Adaptado de Hecker, Lambeck e Toepfer (2009). . . . . . . . . . . . . . . . . . . . . . . . . . . 49

Figura 13 - Exemplos de curvas ROC. (a) Uma curva que indica uma boa inferência. (b) Indica uma inferência razoável. (c) Indica uma inferência ruim. (d) Indica uma inferência aleatória. . . . . . . . . . . . . . . . 51

Figura 14 - Exemplo de Curva Precision-Recall. Neste exemplo percebe-se que o método pode recuperar até $40 \%$ das interações corretamente sem sacrificar a precisão, porém para recuperar $100 \%$ é necessário aceitar uma precisão próxima de $45 \% \ldots \ldots \ldots$. . . . . . . . . . . 52

Figura 15-Um combinador de vários métodos de inferência de GRNs. Cada algoritmo produz a sua própria representação da rede de genes, que são agregadas pelo combinador $\mu_{j}(x) . \ldots \ldots \ldots \ldots 6$

Figura 16 - Arcabouço experimental. Dados simulados do desafio DREAM5 são usados como entrada para os métodos de inferência, os métodos de

\begin{tabular}{|c|c|c|}
\hline inferência são aplicados e a avaliação de desempenho é realizada. & 58
\end{tabular}

Figura 17- $A U R O C$ para as redes inferidas para diferentes tamanhos de conjuntos de dados. Cada valor representa a média $A U R O C$ para os

\begin{tabular}{|l|}
\hline \hline métodos de inferência obtidos a partir de 5 tamanhos de rede diferen- \\
\hline tes (em termos de número de arestas). As linhas horizontais acima \\
\hline das barras mostram o valor de $A U R O C$ para os comitês. . . . . . . \\
\hline Figura 18 - $A U P R$ para as redes inferidas para diferentes conjuntos de dados. \\
\hline Cada valor representa a média $A U P R$ para os métodos de inferência \\
\hline obtidos a partir de 5 tamanhos de rede diferentes (em termos de \\
\hline \hline número de arestas). As linhas horizontais acima das barras mostram \\
\hline \hline o valor de $A U P R$ para os comitês. . . . . . . . . . . . . . . . 65 \\
\hline
\end{tabular}




\section{LISTA DE TABELAS}

Tabela 1 - A transcrição do DNA em RNA e a tradução de RNA em proteína. Adaptado de Jones e Pevzner $(2004$, p. 65). . . . . . . . . . . . . 30

Tabela 2 - Um recorte de uma Matriz de Expressão Gênica. . . . . . . . . . . . 31

Tabela 3 - Comparação das propriedades dos modelos apresentados. São classificados como Estáticos (E) ou Dinâmicos (D), Estocásticos (E) ou Determinísticos (D), Discretos (D) ou Contínuos (C) e de acordo com o nível de informação contida no modelo (Níveis apresentados na Figura 91 . . . . . . . . . . . . . . . . . . 45

Tabela 4 - Dados necessários para diferentes métodos de inferência de GRNs, para redes contendo $N$ genes e conectividade $K$. Adaptado de Alakwaa (2014). . . . . . . . . . . . . . . . . . . . . . 46

Tabela 5 - Matriz de Confusão. . . . . . . . . . . . . . . . . . . . . . . . . . . 49

Tabela 6 - Resumo comparativo de trabalhos relacionados, seus métodos, fonte de dados, número de genes e amostras e métricas utilizadas. . . . 55

Tabela 7 - Métodos de inferência de GRNs analisados. . . . . . . . . . . . 60 



\section{LISTA DE ABREVIATURAS E SIGLAS}
A
Adenina
BN
Rede Booleana (Boolean Network)
$\mathrm{BDe}$
Bayesian Dirichlet Equivalent
C
Citosina
CLR
Context Likelihood of Relatedness
DNA
Ácido desoxirribonucleico (Deoxyribonucleic acid)
FN Falso Negativo (False Negative)
FP Falso Positivo (False Positive)
FPR Taxa de Falso Positivo (False Positive Rate)
G Guanina
GDA Grafo Direcionado Acíclico
GGM Modelo Gráfico Gaussiano (Gaussian Graphical Model)
GRN Rede de Regulação Gênica (Gene Regulatory Network)
MEG Matriz de Expressão Gênica
mRNA RNA mensageiro
PR Precision-Recall
RB Rede Bayesiana
RNA Ácido ribonucleico (ribonucleic acid)
rRNA RNA ribossômico
RNA-seq Sequenciamento de RNA (RNA Sequencing)
ROC Receiver Operator Characteristic
T Timina
$\mathrm{TF}$
Fator de Transcrição (Transcription Factor) 
TN Verdadeiro Negativo (True Negative)

TP Verdadeiro Positivo (True Positive)

TPR Taxa de Verdadeiro Positivo (True Positive Rate)

tRNA RNA de transferência

WGCNA Weighted Gene Co-Expression Network Analysis 


\section{LISTA DE SÍMBOLOS}

$\begin{array}{ll}M E G & \text { Matriz de Expressão Gênica } \\ \mathcal{A} & \text { Conjunto de Arestas do Grafo } \\ \mathcal{V} & \text { Conjunto de Vértices do Grafo } \\ k_{i n} & \text { Grau médio de entrada de cada Vértice do Grafo } \\ k_{\text {out }} & \text { Grau médio de saída de cada Vértice do Grafo } \\ k & \text { Grau médio de cada Vértice do Grafo } \\ G & \text { Gene Amostrado } \\ I & \text { Informação Mútua } \\ P & \text { Correlação de Pearson } \\ H & \text { Entropia de Shannon } \\ A & \text { Matriz de Adjacência } \\ \sigma & \text { Desvio Padrão }\end{array}$



SUMÁRIO

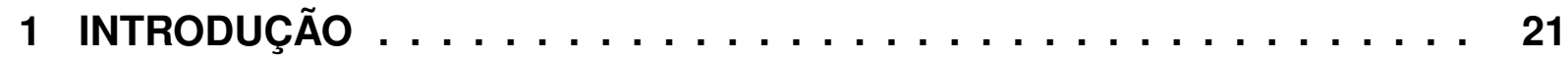

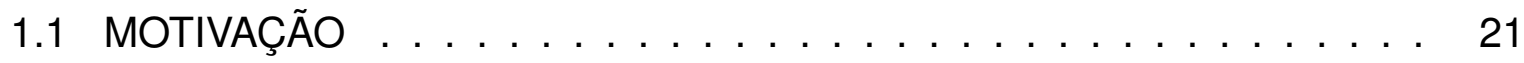

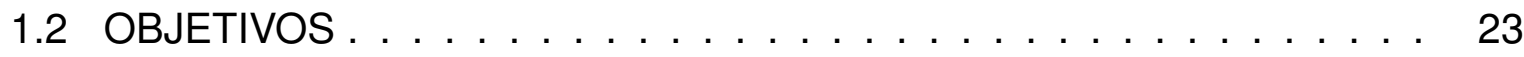

1.3 ORGANIZAÇÃO DO TEXTO $\ldots \ldots \ldots \ldots \ldots \ldots \ldots \ldots$

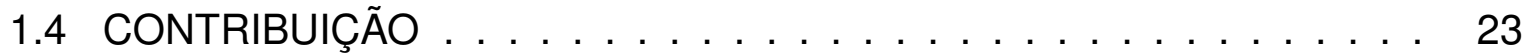

2 CONCEITOS FUNDAMENTAIS $\ldots \ldots \ldots \ldots \ldots \ldots$

2.1 INTRODUÇÃO À BIOLOGIA MOLECULAR . . . . . . . . . . . . 25

2.2 EXPRESSÃO GÊNICA . . . . . . . . . . . . . . . . . . . 28

2.3 REDE DE REGULAÇÃO GÊNICA . . . . . . . . . . . . . 32

3 INFERÊNCIA DE REDES DE REGULAÇÃO GÊNICA $\ldots \ldots \ldots \ldots$

3.1 REDES BOOLEANAS . . . . . . . . . . . . . . . . . . . 37

3.2 REDES BAYESIANAS . . . . . . . . . . . . . . . . . 38

3.3 MODELO GRÁFICO GAUSSIANO . . . . . . . . . . . . . . . 39

3.4 REDES DE CORRELAÇÃO . . . . . . . . . . . . . . . . . . 40

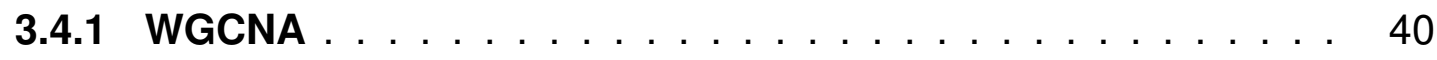

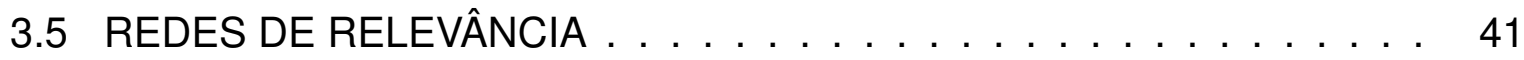

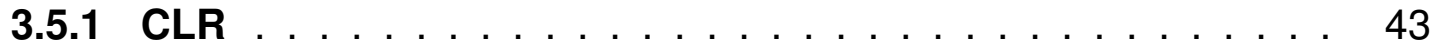

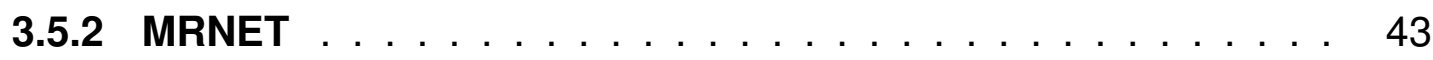

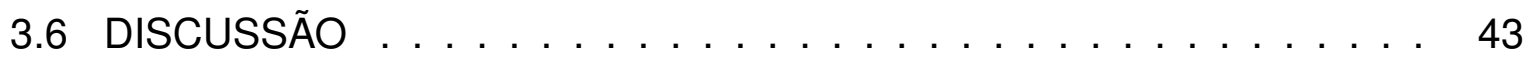

4 METODOLOGIA DE AVALIAÇÃO DE DESEMPENHO $\ldots \ldots \ldots \ldots$

4.1 MÉTRICAS DE AVALIAÇÃO. . . . . . . . . . . . . . . . . 48

5 USANDO COMITÊS PARA MELHORAR A INFERÊNCIA DE REDES GÊNI-

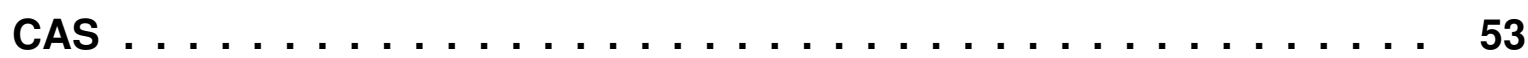

5.1 COMITÊS DE ESPECIALISTAS. . . . . . . . . . . . . . . 55

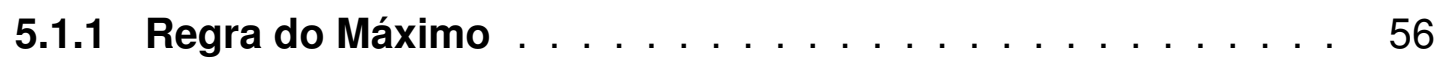

5.1 .2 Regra da Média . . . . . . . . . . . . . . . . . . 57

5.1 .3 Regra da Média Ponderada . . . . . . . . . . . . . . 57

5.1 .4 Classificação pelo Produto . . . . . . . . . . . . . 57

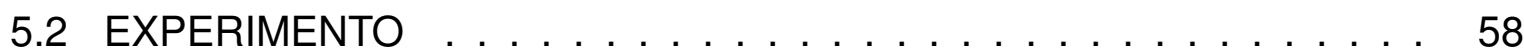

6 RESULTADOS E DISCUSSÃO . . . . . . . . . . . . . . . 63 
7 CONCLUSÕES E TRABALHOS FUTUROS $\ldots \ldots \ldots \ldots \ldots$

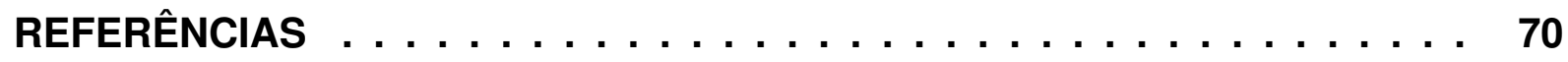




\section{INTRODUÇÃO}

Nos últimos anos os avanços científicos e a evolução das tecnologias de sequenciamento de DNA (ácido desoxirribonucleico) em larga escala resultaram em uma grande quantidade de dados disponíveis sobre o genoma de diversos organismos. Para entender o funcionamento de um organismo, além da função individual de cada gene, proteína, RNA (ácido ribonucleico) e outras moléculas biológicas, é necessário também entender as interações entre eles.

O Dogma Central da Biologia Molecular foi apresentado por Crick et al. (1970) para descrever o processo de transferência sequencial de informação em um sistema biológico. De forma simples, o DNA pode ser copiado para produzir novas moléculas de DNA através do processo de replicação, pode ser copiado em RNA no processo de transcrição e as proteínas podem ser sintetizadas a partir do RNA no processo de tradução. Porém, hoje já se sabe que alguns retrovírus são capazes de utilizar apenas RNA para sintetizar DNA no seu hospedeiro (ALBERTS et al., 2010).

O produto da expressão de um gene pode colaborar com a regulação de outros genes e essas interações podem ser modeladas através de Redes de Regulação Gênicas (GRN, do inglês Gene Regulatory Network), que são capazes de representar as relações de regulação entre os genes, exibindo como as mudanças nas atividades em um ou mais genes podem afetar outros.

As GRNs fornecem uma representação sistêmica dos processos biológicos celulares. Entender estes processos pode ajudar a identificar em quais tecidos alguns genes específicos estão ativos e em quais circunstâncias as proteínas e demais produtos gerados pela expressão gênica aparecem, colaborando no entendimento de processos patológicos e evolucionários (LOPES, 2011).

\subsection{MOTIVAÇÃO}

Investigar as funções, características e interação dos genes é uma das principais motivações da Biologia Molecular (ALBERTS et al., 2010). Os dados gerados pelas novas tecnologias de sequenciamento estão sendo utilizados para responder perguntas sobre a relação dos genes em determinadas funções celulares e quais genes interagem entre si na realização dessas funções. As GRNs são utilizadas em muitas pesquisas para identificar as conexões genéticas e os sistemas de controle responsáveis por características físicas, comportamentais, evolutivas e fisiológicas (SOMEREN et al., 2002). 
Existe muito a ser aprendido sobre os padrões de expressão dos genes e a interação entre eles. No passado as interações moleculares foram descobertas em um ritmo muito lento. Como exemplo, levou mais de uma década para descobrir o gene p53, supressor de tumores e o sistema de feedback regulatório em que está inserido com a proteína MDM2, seu principal regulador (MARBACH et al., 2010).

O mapeamento das interações biológicas no meio da célula é ainda hoje um dos principais desafios da biologia molecular. Ferramentas de análise computacional podem ajudar na criação de novas hipóteses sobre o funcionamento das interações gênicas que podem ser confirmadas ou refutadas. Algoritmos de aprendizado de máquina são interessantes nesse contexto pois conseguem aprender a descrição de conceitos a partir de exemplos e treinamento, não necessitando de um modelo bem definido do problema. Para realizar essa tarefa é importante ter-se métodos precisos para inferência da redes (MARBACH et al., 2010).

A inferência de GRNs a partir de dados de expressão gênica é uma tarefa desafiadora, pois geralmente o número de amostras temporais é muito pequeno e o número de variáveis (genes) analisadas é muito grande, dando uma característica complexa aos dados. Os dados também sofrem a presença de ruído devido a variações causadas por medidas de células em diferentes tecidos e por perturbações externas às células, tornando difícil a construção de GRNs a partir de observações empíricas (SOMEREN et al., 2002).

Vários métodos de inferência de redes baseados em técnicas de mineração de dados são aplicadas para capturar a dinâmica de interação dos componentes celulares como DNA, RNA e proteínas a partir dos dados disponíveis (LIU, 2015; LO et al., 2015; LOPES et al., 2014; WANG; HAIYANHUANG, 2014; CHAl et al., 2014; LANGFELDER; HORVATH, 2008; SCHÄFER; STRIMMER, 2005; FRIEDMAN et al., 2000). A rede inferida pode ajudar a identificar em qual via regulatória os produtos do gene estão inseridos, com quais outros genes esses produtos interagem e quais genes ativam suas vias inibitórias, facilitando a escolha dos genes a serem utilizados como alvos para aplicação de drogas ou para auxiliar em tratamentos médicos (LOPES, 2011).

Apesar de diversos métodos de inferência estarem disponíveis, cada um baseia-se em características e modelos diferentes do sistema de regulação gênica. $O$ desempenho de cada método ainda não é bem compreendido, o que torna necessário sua avaliação para entender melhor seus limites de aplicação (MARBACH et al., 2010). Uma validação sistemática dos métodos propostos é essencial pois consegue evidenciar seus pontos fortes e fracos e auxiliar na escolha de métodos que se adequem a domínios específicos de aplicação. Validar tais abordagens e seus resultados ainda é um problema importante em aberto (IANCU et al., 2012). 
Os resultados esperados deste trabalho são relevantes pois podem auxiliar na análise do grande volume de dados de expressão gênica existente e podem:

- Facilitar na descoberta de doenças genéticas;

- Auxiliar em testes de eficiência de novas drogas e agrupamento de genes que descrevem a mesma função biológica;

- Elucidar os caminhos da evolução e

- Explicar fenômenos fisiológicos e de comportamento.

\subsection{OBJETIVOS}

\subsection{ORGANIZAÇÃO DO TEXTO}

No Capítulo 2 são apresentados conceitos fundamentais da Biologia Molecular para o desenvolvimento da pesquisa proposta. No Capítulo 3 apresenta-se uma revisão sobre os modelos matemáticos de GRNs e métodos de inferência de redes presentes nos trabalhos analisados. No Capítulo 4 apresentamos a metodologia de avaliação utilizada neste trabalho.

Oapítulo 5 apresenta um estudo comparativo das técnicas de comitês de especialistas Regra do Máximo (Maximum Rule), Regra da Média (Mean Rule), Regra da Média Ponderada (Weighted Average) e Classificação pelo Produto (Rank Product) usando os métodos CLR, GeneNet, MRNET e WGCNA como base. No Capítulo 6 apresentam-se os resultados obtidos. No Capítulo 7 são apresentadas as conclusões deste trabalho e indicações de trabalhos futuros.

Em suma, este trabalho oferece uma discussão acerca de métodos de inferência de GRNs por meio de uma análise comparativa de métodos bem difundidos na literatura e a proposta do uso de comitês de especialistas com o objetivo de realizar a inferência de GRNs de forma mais precisa.

\subsection{CONTRIBUIÇÃO}

Neste trabalho realizamos uma avaliação comparativa de métodos de inferência de GNRs e de técnicas de comitês de especialistas em conjuntos de dados com poucas amostras. Mostramos que uma quantidade reduzida de amostras afeta a qualidade de inferência das redes e que a aplicação de comitês de especialistas pode melhorar a qualidade de inferência das redes; porém, também destacamos que o impacto dessas técnicas é muito baixo quando são aplicadas em conjuntos de dados com poucas 
amostras. Esses resultados foram publicamos no artigo Using Ensemble Combiners to Improve Gene Network Inference (FACHINI; MARTINS; COSTA, 2015) apresentado no Workshop BAl 2015: Advances in Bioinformatics and Artificial Intelligence: Bridging the Gap, IJCAI 2015. 


\section{CONCEITOS FUNDAMENTAIS}

Neste trabalho o interesse está na análise computacional de dados de expressão gênica. Porém, para uma compreensão dos métodos avaliados e da proposta apresentada, é necessário entender alguns conceitos fundamentais da biologia molecular. Nas seções a seguir apresenta-se uma introdução sobre a célula e sua estrutura interna, sobre o DNA (ácido desoxirribonucleico), RNA (ácido ribonucleico) e proteínas seção 2.1), a Regulação da Expressão Gênica (seção 2.2), a definição de GRNs e como realizar sua inferência (seção 2.3). Para maiores informações sobre esses conteúdos relacionados à biologia molecular, indica-se a leitura do livro Biologia Molecular da Célula (ALBERTS et al., 2010). Para um aprofundamento nos conceitos relacionados à Bioinformática recomenda-se a leitura das obras Introduction to Bioinformatics (LESK, 2014) e An Introduction to Bioinformatics Algorithms (JONES; PEVZNER, 2004).

\subsection{INTRODUÇÃO À BIOLOGIA MOLECULAR}

A maioria dos organismos vivos é unicelular; outros, como os seres humanos, são multicelulares. Existem nos organismos uma grande variedade de células com as mais diversas funções, porém todas compartilham características organizacionais em comum. As áreas de estudo da biologia celular e molecular buscam entender essas características das células e das moléculas que a constituem. Ao se realizar uma análise no nível celular, pode-se dividir os organismos vivos em dois grupos: os procariontes e os eucariontes.

Os procariontes são organismos unicelulares, englobando os domínios das Bactérias e Archaea. As células desses organismos se caracterizam por não possuírem núcleo bem diferenciado (sem uma membrana), sendo que seu cromossomo fica em contato direto com o protoplasma (ALBERTS et al., 2010, p. 1).

O grupo dos organismos eucariontes inclui todos os demais organismos unicelulares ou pluricelulares. Entre suas principais características pode-se destacar a presença de um núcleo celular rodeado por uma membrana (a carioteca) e diversas organelas não presentes nas células procariontes. Neste tipo de célula, os processos de transcrição e de tradução são eventos separados realizados em diferentes regiões da célula (ALBERTS et al., 2010, p. 1).

Os ácidos nucleicos (DNA e RNA) foram descobertos em 1869 pelo físico e biólogo Johann $F$. Miescher que os isolou em experimentos realizados com as células brancas do sangue. No começo do século XX já se sabia que o DNA era uma molécula comprida 
formada por quatro tipos de bases e em 1920 os ácidos nucleicos foram divididos em ácido desoxirribonucleico e ácido ribonucleico (JONES; PEVZNER, 2004). Em 1953, Watson e Crick apresentaram para a comunidade científica a estrutura de dupla-hélice da molécula de DNA (WATSON; CRICK, ). Nos anos noventa, o Projeto Genoma Humand 1 iniciou esforços para o mapeamento do genoma humano e a identificação dos genes que codificam as proteínas. Apesar de todo o desenvolvimento tecnológico e das descobertas realizadas, ainda se entende pouco sobre como genes específicos são regulados, mesmo em organismos mais simples.

O ciclo básico de vida das células envolve o nascimento, crescimento, diferenciação e morte. Todas as atividades celulares são coordenadas por uma rede complexa de comunicação através de reações químicas organizadas em vias metabólicas Pathways. Nessas, novos elementos são sintetizados, outros são divididos, e sinais que indicam, por exemplo, se a célula precisa se alimentar ou vai morrer, são enviados. Apesar de existirem células que realizam diferentes funções, todas dependem de três moléculas para a manutenção da vida: o DNA, o RNA e as proteínas (JONES; PEVZNER, 2004). Nas células dos eucariontes, o DNA está organizado junto com proteínas nos cromossomos no núcleo. Já o RNA pode ser localizado tanto no núcleo, onde é transcrito, quanto no citoplasma, onde participa da síntese das proteínas (ALBERTS et al., 2010, p. 4).

Todas as células conhecidas armazenam suas informações hereditárias na forma de moléculas de DNA de fita dupla. Uma fita de DNA é uma cadeia de nucleotídeos compostos por polímeros formados por uma sequência de açúcares (desoxirribose) ligados por ácido fosfórico (grupo fosfato) com uma base nitrogenada projetando-se dela (Figura 1a). A base pode ser: A (adenina), C (citosina), T (timina) e G (guanina). As fitas do DNA são complementares e opostas. As bases $A$ e $T$, e $C$ e $G$ formam pares complementares. A ligação entre as fitas se dá por pontes de hidrogênio. Dada a ordem de bases em uma fita, a outra deve ser complementar. As unidades de açúcar e fosfato são assimétricas, dando uma orientação assimétrica para a cadeia, garantindo que os processos moleculares pelos quais o DNA é interpretado sejam sempre realizados na mesma ordem. As extremidades das fitas de DNA são chamadas de 3' e 5'. A extremidade 3' de uma fita corresponde à extremidade 5' da outra fita (ALBERTS et al., 2010, p. 2-3). A Figura 1 apresenta os elementos que compõem o DNA e a sua estrutura de dupla-hélice.

Como as pontes de hidrogênio são mais fracas que as ligações entre os açúcares e os fosfatos, quando o processo de replicação do DNA ocorre as duas fitas são separadas de forma que não ocorram danos. Cada fita serve de molde para a síntese

1 Projeto Genoma Humano: http:www.genome.gov10001772 


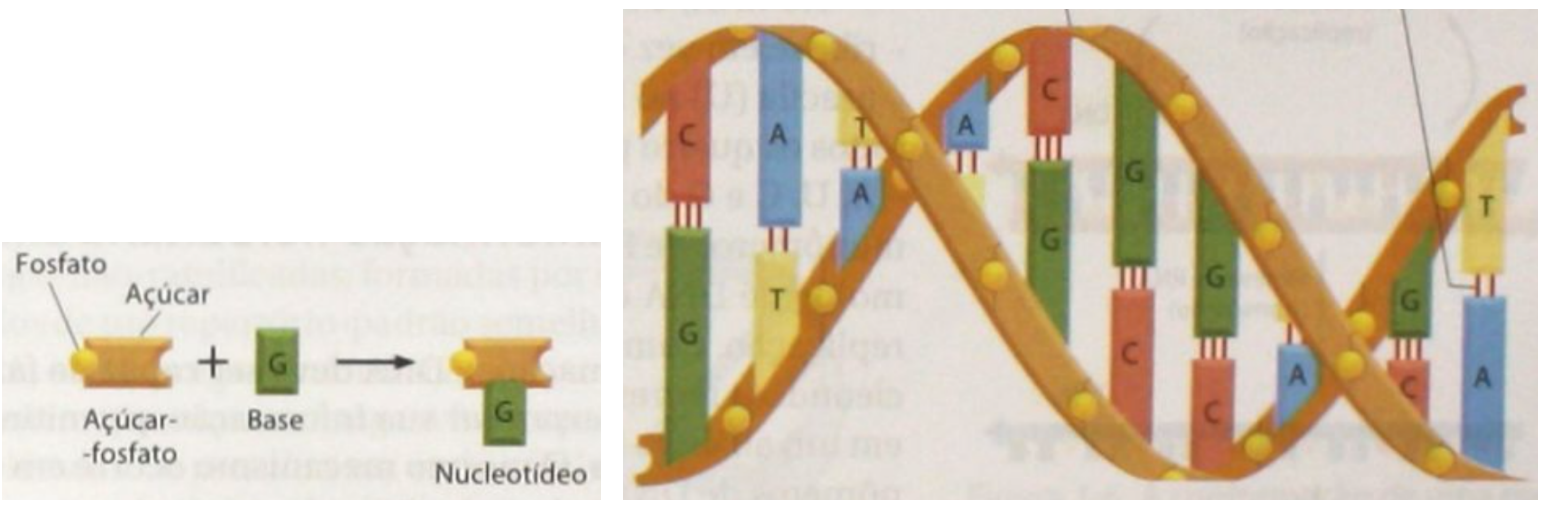

(a)

(b)

Figura 1 - Estrutura do DNA. (a) Nucleotídeos, constituídos de açúcar, fosfato e uma base. (b) As duas fitas formando uma dupla-hélice evidenciando o empareIhamento entre as bases complementares. Adaptado de Alberts et al. (2010, p. 3).

de uma nova fita de DNA complementar (ALBERTS et al., 2010).

O RNA é um polímero quimicamente parecido com o DNA, composto por uma única fita, na qual o nucleotídeo T é substituído pelo nucleotídeo U (uracil) e o açúcar é a ribose, este difere da desoxirribose por conter um átomo de oxigênio a mais (LESK, 2014). Enquanto o DNA é uma molécula inerte servindo para o armazenamento de informação, o RNA é uma molécula mais ativa. O DNA é transcrito em uma molécula de RNA mensageiro (mRNA), fenômeno que ocorre no núcleo. Esta molécula de mRNA migra para o citoplasma onde é traduzido ou não em uma proteína. (JONES; PEVZNER, 2004). Alguns vírus são muito simples e não possuem DNA, tendo seu genoma composto apenas por moléculas de RNA.

O genoma de um organismo é representado pelo conteúdo de DNA. Mesmo os organismos mais simples possuem uma sequência longa, tipicamente de $10^{6}$ nucleotídeos ou mais. O gene é uma porção dessa sequência que codifica informação para a síntese de proteína, RNAs funcionais ou para definir características dos organismos. No genoma humano, os genes correspondem a apenas $3 \%$ da sequência e acredita-se que o restante não conhecido pode ser resquício da evolução ou tem função na própria regulação da expressão dos genes (LESK, 2014). O genoma é transmitido de geração para geração através da formação dos gametas e fecundação. Durante a replicação do material genético e divisão celular ocorrem imperfeições que são responsáveis por gerar mutações na cadeia de DNA replicada, modificando características físicas dos organismos vivos.

Existem diversos tipos de ácidos ribonucleicos, sendo três envolvidos na síntese de proteínas. O mRNA (RNA mensageiro) contém a informação genética para gerar a 
sequência de aminoácidos. O tRNA (RNA de transferência) é responsável por identificar e transportar as moléculas de aminoácidos até o ribossomo. O rRNA (RNA ribossômico) forma a estrutura onde o mRNA é traduzido em proteínas (ALBERTS et al., 2010).

As proteínas são, depois da água, as moléculas mais presentes dentro das células. Elas são moléculas constituídas de aproximadamente vinte aminoácidos presentes em diversas proporções, e a ordem em que os aminoácidos estão organizados dá origem a um grande número de moléculas de proteína que exercem funções diferentes nas células, como: a manutenção de estruturas, ação de enzimas, percepção e envio de sinais para outras células, participação em outros componentes celulares como a pele e queratina, fornecimento de resposta imune e também de funcionamento como fator de transcrição (TF) (ALBERTS et al., 2010; JONES; PEVZNER, 2004).

A sequência de três nucleotídios consecutivos do DNA (chamadas de códons) são responsáveis por codificar uma sequência de aminoácidos nas proteínas que, por sua vez, são responsáveis por diversas reações químicas incluindo as que sintetizam novas moléculas de DNA, retroalimentando o sistema (ALBERTS et al., 2010). Cada códon é codificado em um aminoácido, que é usado na construção das proteínas. Este processo de codificação é conhecido como código genético. As proteínas são sintetizadas após o processo de tradução do RNA; porém, como o RNA é transcrito a partir do DNA apenas trocando a timina por uracil, pode-se representar os dois processos separados em apenas um passo.

O DNA fica organizado nos cromossomos no interior do núcleo celular. Os cromossomos estão presentes em pares, em diferentes tamanhos e formatos, sendo cada membro do par chamado de cromossomo homólogo. Cada espécie possui uma quantidade diferente de cromossomos; a espécie humana possui 23 pares (ALBERTS et al., 2010).

O gene é formado por um conjunto de nucleotídios e possui alguma função, como por exemplo, a produção de determinada proteína. Os genes podem ser divididos em três grupos: os que não são transcritos, os transcritos e os transcritos e traduzidos. Os genes aparecem em pares chamados de alelos, cada um em um cromossomo homólogo (ALBERTS et al., 2010).

\subsection{EXPRESSÃO GÊNICA}

O DNA de um ser vivo possui milhares de genes. Apesar das células possuírem praticamente o mesmo DNA, elas se comportam de forma diferente dependendo de como os genes são regulados (LESK, 2014). A expressão gênica é o processo no qual um gene pode ser ativado (ou não), resultando em sua transcrição em RNA e a tradução deste em uma proteína. Muitos RNAs são funcionais ou estruturais e 
não traduzidos (ALBERTS et al., 2010). Os passos envolvidos na expressão gênica incluem a transcrição do DNA, o RNA splicing, a tradução do RNA e a modificação póstraducional da proteína. A regulação da expressão gênica é o que controla as funções e estruturas da células, dando origem aos fenótipos de um organismo vivo (BRAZHNIK; FUENTE; MENDES, 2002). A Figura 2 apresenta um diagrama que representa os processos envolvidos na expressão gênica.

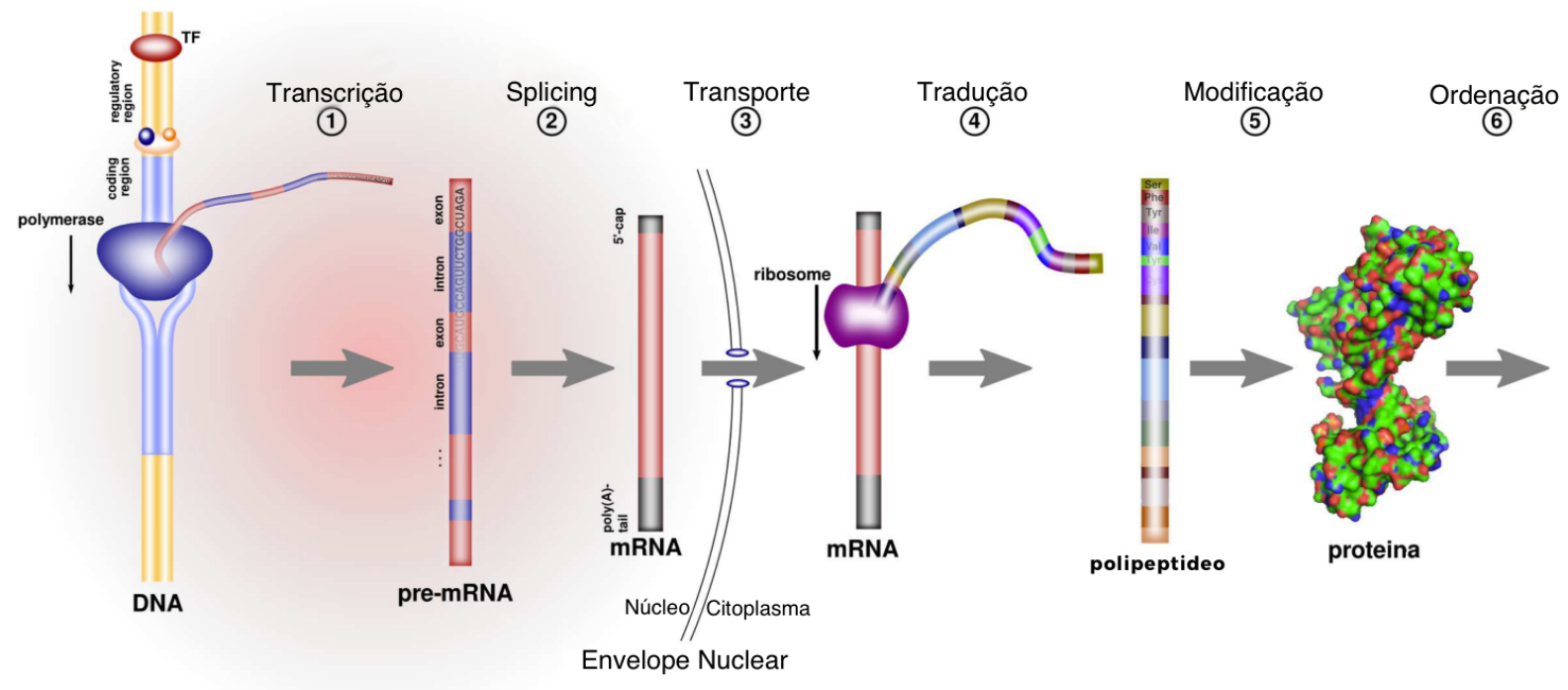

Figura 2 - Expressão Gênica. Adaptado de Gardner e Faith (2005).

O processo de transcrição do DNA envolve a cópia de apenas alguns genes e não do genoma completo. Este processo gera o mRNA, tRNA e rRNA. Chama-se de transcriptoma o conjunto de RNAs transcritos em um determinado momento do ciclo celular. Este processo é realizado pela enzima RNA-polimerase que se liga à fita dupla do DNA e utiliza uma das fitas como modelo e a lê no sentido 3' para 5'. Para iniciar o processo de transcrição, a RNA-polimerase precisa localizar sinais na molécula de DNA indicando a região a ser transcrita, ou seja, o gene. A fita dupla do DNA é aberta e, um a um, os ribonucleotídeos são copiados para a nova fita de RNA. O fim do processo de transcrição é indicado por uma sequência de nucleotídeos chamada de terminadora da transcrição. A molécula de RNA resultante é antiparalela e complementar à fita modelo de DNA com o uracil no lugar da timina. Ao terminar o processo, a RNA-polimerase arruma as fitas de DNA em sua configuração original de dupla-hélice (ALBERTS et al., 2010; JONES; PEVZNER, 2004). A região composta pela região promotora, código genético e região terminadora pode estar sujeita à regulação gênica (MENDOZA, 2014 , p. 40).

As regiões promotoras são reguladas pelos Fatores de Transcrição (TFs), capazes de reconhecer padrões específicos dessa região do DNA, chamados de motivos (motif), onde se ligam para ativar ou inibir o processo de transcrição (MENDOZA, 2014). Os 
TFs exercem função importante no ciclo celular. Quando a célula precisa realizar determinado processo, os TFs são utilizados para ativar a expressão deste gene. Caso algum gene não seja necessário, os TFs inibem sua expressão (ALBERTS et al., 2010). A Figura 3 apresenta o processo de transcrição do DNA e a síntese de RNA pelo RNA-polimerase.

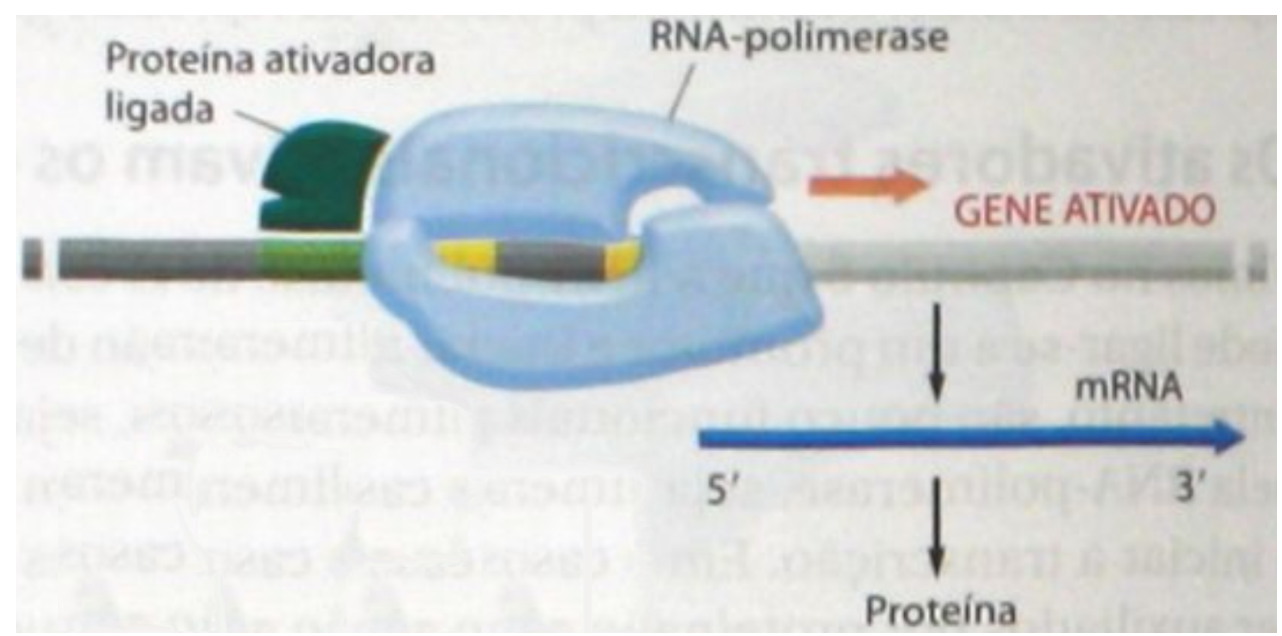

Figura 3 - Representação do RNA Polimerase, processo pelo qual se dá a transcrição dos genes. Adaptado de Alberts et al. (2010, p. 436).

Após ser transcrito, o mRNA é modificado em um processo chamado de RNA splicing. Os introns (sequências geralmente não codificantes) são removidos e os éxons (que permanecerá no mRNA e que será traduzida em proteína) vizinhos são emendados (ALBERTS et al., 2010).

$\mathrm{Na}$ tradução as proteínas são sintetizadas em um aparato (complexo) composto pelos ribossomos, tRNAs e proteínas. Após o mRNA ser sintetizado a partir do DNA, o tRNA funciona como um adaptador entre o mRNA e os ribossomos, transportando as moléculas de aminoácidos para a síntese de proteína. Cada aminoácido é transportado por tRNAs específicos. A síntese de proteína começa quando o mRNA, tRNA e as substâncias de um ribossomo se unem para formar um ribossomo funcional. O ribossomo então percorre o mRNA traduzindo os códons (sequência de três nucleotídios consecutivos) em aminoácidos, passando de um alfabeto de quatro bases para vinte aminoácidos (ALBERTS et al., 2010; JONES; PEVZNER, 2004). A Tabela 1 apresenta as moléculas resultantes na transcrição do DNA em RNA e na tradução de RNA em proteína.

A proteína é um dos produtos finais da expressão gênica. Quando as proteínas agem como TF, elas são responsáveis por ativar ou inibir a expressão de outros genes gerando um processo de retroalimentação. Os processos de tradução e modificação pós-traducional também podem sofrer influência de moléculas reguladoras. No processo 
Tabela 1 - A transcrição do DNA em RNA e a tradução de RNA em proteína. Adaptado de Jones e Pevzner (2004, p. 65).

DNA: TAC CGC GGC TAT TAC TGC CAG GAA GGA ACT

RNA: AUG GCG CCG AUA AUG ACG GUC CUU CCU UGA

Proteína: Met Ala Pro lle Met Thr Val Leu Pro Stop

de modificação pós-traducional as proteínas sofrem modificações químicas (GARDNER; FAITH, 2005).

Um gene é considerado expresso quando seu produto correspondente está presente nas células. Geralmente quando o processo de transcrição está sendo realizado, também ocorre o processo de tradução e a expressão gênica está ativa. Por esta razão, muitas técnicas experimentais medem o nível de transcritos em uma célula como forma de medir a expressão gênica (MENDOZA, 2014, p. 42). As tecnologias de análise em larga escala como DNA microarray e RNA-Seq possibilitaram a coleta massiva de dados genômicos, tornando possível a medição do nível de expressão de múltiplos genes de forma simultânea (HECKER; LAMBECK; TOEPFER, 2009).

Enquanto a sequência de DNA nos fornece o que a célula pode fazer, o perfil de expressão gênica é uma amostra temporal do estado da expressão gênica sob determinadas condições. Apesar de todas as células possuírem a informação genética capaz de produzir o mRNA, apenas uma pequena parte dos genes são ativados dependendo da função da célula. Fatores como o período do dia, a divisão celular, o tipo de ambiente onde o organismo está inserido e sinais químicos influenciam em quais genes serão ativados.

Esse tipo de análise gera os perfis de expressão gênica que podem ser utilizados para identificar genes em condições de interesse, como por exemplo testes de células doentes e submetidas a um tratamento, bem como acompanhar o comportamento dos genes envolvidos em processos celulares durante um período de tempo (LOPES, 2011). A análise da expressão de um gene pode fornecer pistas sobre os mecanismos de regulação e interação dos genes, em quais tecidos determinados genes estão ativos e em quais circunstâncias as proteínas e demais produtos gerados pela expressão gênica aparecem, colaborando no entendimento de processos patológicos e evolucionários (LOPES, 2011).

Para fins de análise computacional, os dados de expressão são representados por uma Matriz de Expressão Gênica (MEG), onde as linhas são perfis de expressão dos genes e as colunas, os experimentos (FILKOV, 2005). Sendo $M E G$ a matriz, o perfil de expressão gênica é dado pelas linhas $M E G_{i}$ e o nível de expressão gênica é dado por $M E G_{i j}$, as colunas representam experimentos amostrados em tempos diferentes ou indivíduos distintos. A Tabela 2 apresenta um exemplo dessa matriz. 
Tabela 2 - Um recorte de uma Matriz de Expressão Gênica.

\begin{tabular}{c|c|c|c|c} 
& Amostra $_{1}$ & Amostra $_{2}$ & $\cdots$ & Amostra $_{m}$ \\
\hline Gene $_{1}$ & 0.54 & -0.34 & $\cdots$ & 0.65 \\
Gene $_{2}$ & -0.12 & 0.23 & $\ldots$ & 0.12 \\
$\vdots$ & $\vdots$ & $\vdots$ & $\ldots$ & $\vdots$ \\
Gene $_{n}$ & -0.43 & 0.05 & $\ldots$ & 0.45
\end{tabular}

De modo geral, uma MEG representa o estado de milhares de genes em apenas algumas dezenas de experimentos, sofrendo da maldição da dimensionalidade. Este fato torna-se um problema sério para a aplicação de técnicas inteligentes com a intenção de inferir modelos a partir dos dados de treinamento. A falta de dados para treinamento também causa um super ajuste (overfitting), onde o modelo aprendido torna-se muito complexo e incapaz de generalizar corretamente quando novos dados são apresentados. Para gerar modelos confiáveis é recomendado possuir uma quantidade de amostras (experimentos) exponencialmente superior à quantidade de variáveis (genes), porém estes dados geralmente não estão disponíveis.

Devido ao fato de que um gene pode interferir na regulação de outros genes, a análise de conjuntos de genes é mais interessante do que sua análise individual. Podese descobrir através das redes de genes que os produtos de um certo gene ativa outro gene, indicando processos biológicos importantes.

\subsection{REDE DE REGULAÇÃO GÊNICA}

Um sistema de regulação gênica consiste de genes, proteínas exercendo função de TFs, RNA e outros metabólitos. A interação das moléculas reguladoras com as regiões promotoras do DNA controla o nível de expressão durante o processo de transcrição (FILKOV, 2005). Sendo assim, o gene responsável pela produção destas moléculas reguladoras é capaz de regular a expressão de outros genes. Tanto em organismos simples como em complexos, existem evidências de que os genes que produzem proteínas e que interagem entre si tendem a compartilhar expressões gênicas e funções similares no sistema (SHARAN; ULITSKY; SHAMIR, 2007). Pode-se utilizar uma GRN como abstração matemática e gráfica para representar um conjunto de genes e suas interações regulatórias. Esta representação das relações de interação é conveniente pois pode fornecer uma ideia geral e melhorar o entendimento global e local do sistema de regulação. Existem diversos tipos de redes capazes de representar informações biológicas, como por exemplo redes de interação proteína-proteína, redes metabólicas, vias de sinalização celular, redes filogênicas e Redes de Regulação Gênica (HACHE, 2009). Neste trabalho iremos focar nesta última: as GRNs. 
GRNs são representações sucintas do conhecimentos sobre o sistema estudado. Elas podem ser usadas para classificação dos genes baseada na sua localização no sistema, entender a influência de um gene em outros no processo de regulação e a influência de genes nos fenótipos dos organismos. A Figura 4 mostra um recorte de um sistema de regulação gênica hipotético.

\section{Gene $1 \quad$ Gene $2 \quad$ Gene 3}

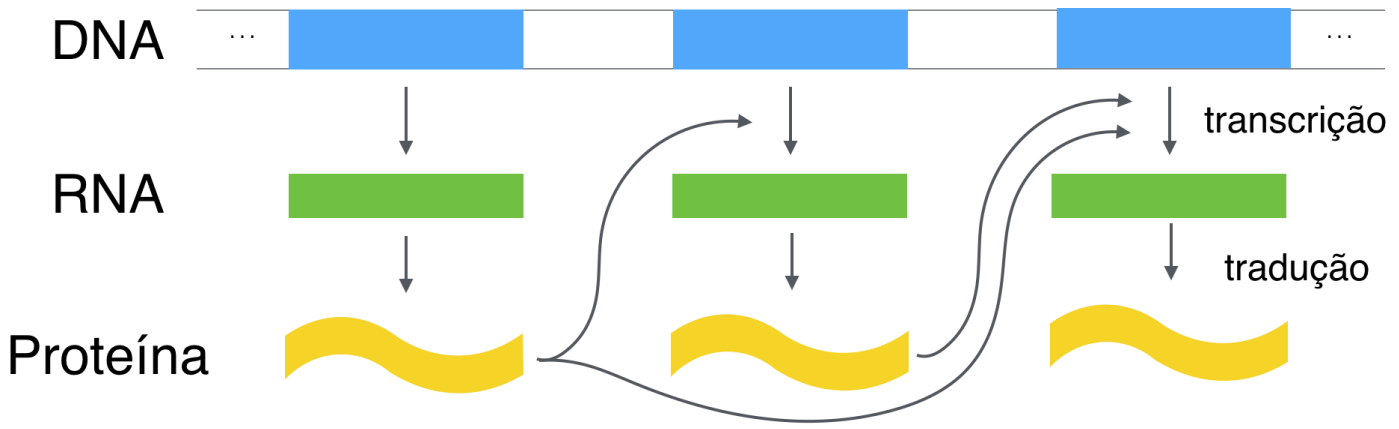

Figura 4 - Recorte de um sistema de regulação gênica. Genes são transcritos em RNA que são traduzidos em proteínas que nesse exemplo agem como fatores de transcrição de outros genes. O Gene1 atua na expressão do Gene2 e Gene3. Adaptado de Hecker, Lambeck e Toepfer (2009).

Formalmente, pode-se representar uma GRN através de um grafo direcionado $G R N=(\mathcal{V}, \mathcal{A})$ onde os vértices $\mathcal{V}=\left\{v_{1}, \cdots, v_{n}\right\}$ são genes, TFs ou mRNA e as arestas $\mathcal{A}=\left\{\left(v_{i}, v_{j}\right): v_{i}, v_{j} \in \mathcal{V}\right\}$ são sinais emitidos que representam interações regulatórias (síntese de RNA, proteínas) pela expressão de um gene regulador $v_{i}$ para um gene $v_{j}$ (HACHE, 2009). Uma interação regulatória pode ser de ativação (1) ou de inibição (-1) ou neutra (0) (LOPES, 2011). Na Figura 5 são apresentadas as representações na forma de matriz, grafo e lista de adjacências para outro sistema.

1
2
3
4 $\left[\begin{array}{rrrl}0 & 2 & 3 & 4 \\ 0 & 0 & 0 & 0 \\ 1 & -1 & 0 & 0 \\ 1 & 0 & 1 & 0\end{array}\right]$

(a)

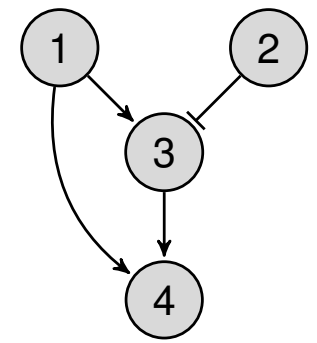

(b)

\begin{tabular}{c|c|c} 
Regulador & Alvo & Regulação \\
\hline 1 & 3 & 1 \\
1 & 4 & 1 \\
2 & 3 & -1 \\
3 & 4 & 1
\end{tabular}

(c)

Figura 5 - Representações de uma GRN, (a) matriz de adjacência, (b) grafo e (c) lista de adjacência. Adaptado de Hache (2009, p. 11).

A representação na forma de lista de adjacência é especialmente conveniente para os experimentos que serão realizados neste trabalho. Enquanto a matriz é mais 
conveniente para realizar uma exploração matemática, a lista de adjacência permite representar a rede de regulação de forma mais compacta.

As GRNs possuem uma topologia esparsa. Esta característica deriva de observações experimentais nas quais descobriu-se que os genes observados são regulados por uma quantidade constante e pequena de outros genes (FILKOV, 2005). O conhecimento desta característica é importante pois pode-se utilizá-la para elaborar abordagens de redução do espaço de busca nos métodos de inferência de GRNs.

A conectividade dos genes em uma GRN segue uma distribuição de lei de potência (Figura 6), caracterizando uma rede livre de escala, muito comum em redes biológicas (JEONG et al., ). Esta distribuição é dada por $P(k)=k^{-\mathcal{Y}}$, onde $k$ é o grau médio de cada vértice do grafo, e $\mathcal{Y}$ é a constante que determina a probabilidade de $P(k)$, ou seja, $P(k)$ diminui se $k$ aumenta. Estas redes se caracterizam por conter muitos vértices pouco conectados e poucos com muitas conexões formando pontos centrais (hubs) na rede (Figura 7), representando genes que sofrem muita regulação de outros genes (FILKOV, 2005; MENDOZA, 2014, p. 45).

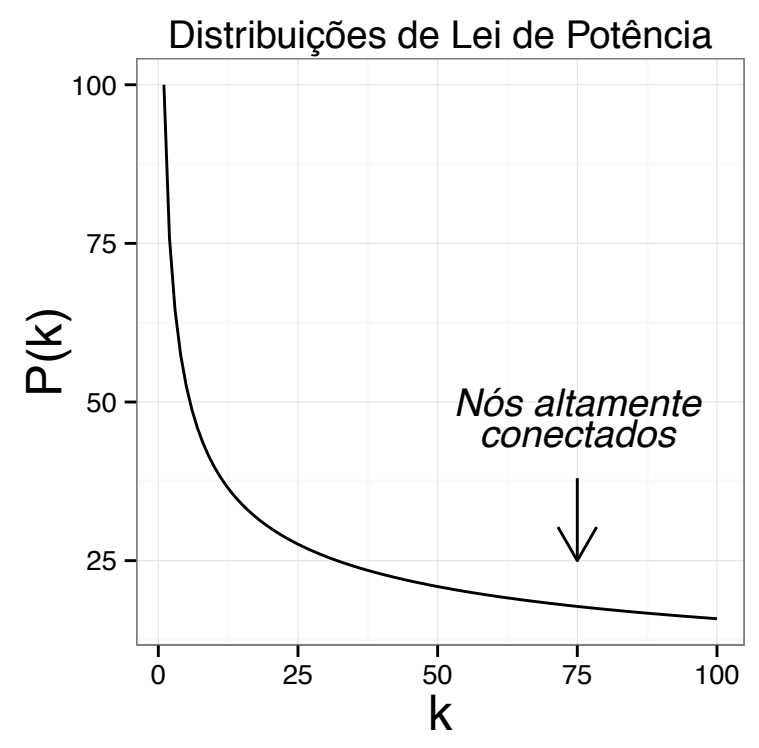

Figura 6 - Redes livres de escala são caracterizadas por uma distribuição de lei de potência, $P(k)=k^{-\mathcal{Y}}$, onde $k$ é o grau médio de cada vértice do grafo, e $P(k)$ a probabilidade.

A representação gráfica das GRNs é uma simplificação das redes de regulação reais. Proteínas e RNAs são abstraídos e todas as interações são mapeadas para os seus genes codificantes. Apesar desta simplificação, as GRNs são uma ferramenta valiosa para entender a relação entre os genes nas células e como eles respondem a estímulos internos e externos. GRNs podem ser úteis para: identificar módulos funcionais nos 


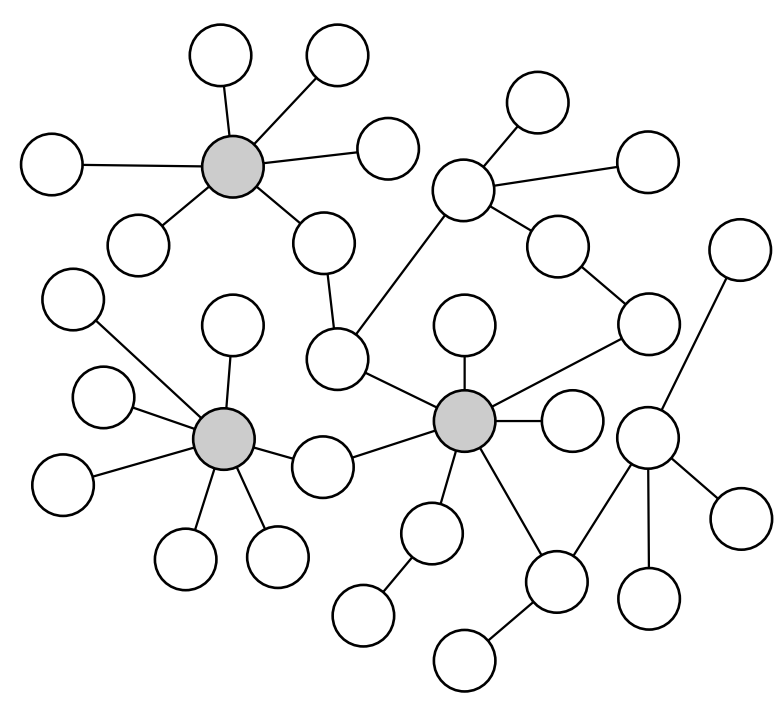

Figura 7 - Uma rede livre de escala e seus hubs (vértices cinzas e com maior grau que os outros).

organismos; identificação das respostas da rede a perturbações externas através de experimentos computacionais (in silic ${ }^{2}$ ); investigação dos mecanismos de doenças complexas; identificação de genes alvos para o desenvolvimento de novas drogas e tratamentos; desenvolvimento de novos paradigmas na medicina como tratamentos personalizados (MENDOZA, 2014).

Apesar de modelos de GRNs de organismos simples como, por exemplo, a levedura estarem disponíveis, ainda se conhece muito pouco sobre os sistemas das GRNs. Como a quantidade de dados gerada pelas tecnologias de análise em larga escala é muito grande, é difícil gerar informações a partir de uma análise sequencial do DNA. Técnicas computacionais sofisticadas são capazes de extrair informações úteis desses dados, como por exemplo, as relações de regulação entre os genes.

Modelar GRNs e realizar a sua inferência $]^{3}$ ainda é um problema em aberto e desafiador. Para realizar a reconstrução da rede é necessário saber, para cada gene, quais os genes que o afetam e como o afetam (SOINOV; KRESTYANINOVA; BRAZMA 2003).

A inferência de GRNs não é uma tarefa computacional fácil. Geralmente o número de amostras temporais é muito pequeno e o número de variáveis (genes) analisadas

2 In silico é uma expressão utilizada para indicar experimentos realizados através de simulações computacionais, derivada das expressões in vivo e in vitro, muito utilizadas na biologia.

3 Neste trabalho adotamos a palavra inferência para se referir à construção de redes a partir dos dados de expressão gênica. Em outros trabalhos pode-se encontrar também o uso dos termos reconstrução e engenharia reversa. 
é muito grande, dando uma característica complexa aos dados. Este problema é conhecido como problema da dimensionalidade, onde o número de medidas é muito menor que o número de variáveis (HECKER; LAMBECK; TOEPFER, 2009).

O problema da dimensionalidade faz com que a estimativa dos parâmetros dos métodos de inferência se torne incerta, podendo-se obter diversas soluções possíveis de estruturas de redes. A solução tradicional para se diminuir a complexidade dos métodos é aplicar restrições aos seus parâmetros. A busca pelos parâmetros que melhor descrevem o modelo é computacionalmente intratável mesmo para os modelos mais simples. Heurísticas devem ser aplicadas, mas mesmo assim, geralmente 0 desempenho dos algoritmos é sub-ótimo (HECKER; LAMBECK; TOEPFER, 2009).

Apesar de estarem disponíveis muitos perfis de expressão gênica, a quantidade de medições não é suficiente para se ter a visão completa do sistema de regulação gênica (LOPES, 2011). Os dados experimentais possuem característica estocástica pois as medições estão sujeitas a ruídos inseridos pela tecnologia de leitura e pelo ambiente onde os experimentos foram realizados. Ainda pode ser possível que os experimentos tenham sido mal realizados, fornecendo dados pouco informativos (HECKER; LAMBECK; TOEPFER, 2009). Seria necessário medir o nível de expressão de um gene muitas vezes sob as mesmas condições experimentais para se conseguir resultados realmente confiáveis, porém geralmente os experimentos possuem poucas amostras para muito genes (SOMEREN et al., 2002). Isso deve-se ao alto custo do processo, do tempo necessário e das dificuldades experimentais envolvidas.

No Capítulo 3 são apresentados os principais modelos matemáticos de GRNs e alguns métodos de inferência que os utilizam e que serão utilizados nos experimentos deste trabalho. 


\section{INFERÊNCIA DE REDES DE REGULAÇÃO GÊNICA}

Este capítulo apresenta uma revisão dos principais modelos matemáticos de Redes de Regulação Gênica e os métodos de inferência mais importantes presentes na literatura. Como a inferência de GRNs é ainda um problema em aberto, pode-se encontrar na literatura diversos métodos que abordam este problema. Aqui o interesse é nos modelos matemáticos fundamentais e nos métodos utilizados na inferência destes modelos.

A inferência de GRNs é ponto fundamental para entender os processos celulares através de modelos de interação dos genes. Pode-se utilizar métodos computacionais para realizar a inferência a partir de dados de expressão gênica. A escolha do modelo adequado para a inferência depende de diversos fatores como: quantidade de dados, dimensionalidade, ruído e se os dados são séries temporais. Uma discussão sobre esses fatores é apresentada na seção 3.6. Os métodos mais comuns atualmente utilizam dados de mRNA, porém quanto mais dados vão se tornando disponíveis, outros tipos de fontes de dados podem ser incorporados para melhorar a qualidade de inferência dos métodos.

Nos últimos anos inúmeros métodos foram desenvolvidos e aplicados na inferência da estrutura e regras de dinâmica de GRNs a partir de diferentes fontes de dados como por exemplo dados de expressão gênica. Neste capítulo apresentamos uma visão geral dos principais trabalhos desenvolvidos na área e realizamos uma avaliação de seus pontos fortes e fracos. Os modelos apresentados neste capítulo foram escolhidos com base na sua relevância na literatura, resultados promissores e também com base na disponibilidade de bibliotecas de software de fácil uso. Entre os modelos matemáticos mais comuns pode-se citar: Redes Booleanas, Redes Bayesianas, Redes de Correlação, Redes de Relevância e Modelo Gráfico Gaussiano, revisados nas seções subsequentes.

\subsection{REDES BOOLEANAS}

Redes Booleanas é um dos modelos computacionais mais simples, sendo utilizado para a modelagem de GRNs pela primeira vez por Stuard Kauffman (KAUFFMAN, 1971). Este modelo fornece uma visão dinâmica e discreta de GRNs e se baseia no princípio de que os genes podem ser abstraídos como chaves binárias assumindo os estados ligado (1) ou desligado (0). As relações entre os genes são formuladas como funções lógicas para representar aspectos da regulação gênica através de séries temporais 
(LIANG; FUHRMAN; SOMOGYI, 1998). Por trabalhar com dados discretos, este modelo precisa passar por uma fase de pré-processamento dos dados de expressão gênica antes de ser aplicado (HECKER; LAMBECK; TOEPFER, 2009).

Apesar de reduzir a regulação gênica em estados binários, este modelo é capaz de representar características fundamentais da regulação gênica, fornecendo uma visão simples e de fácil compreensão de como um determinado sistema de regulação funciona ao invés de focar em detalhes quantitativos complexos. Este modelo vem sendo aplicado em experimentos para descrever relações regulatórias reais, como por exemplo a rede da Drosophila, bem como descrever fenótipos de organismos (XIAO, 2009).

A inferência em métodos que utilizam este modelo consiste em buscar a função que representa cada gene na rede tal que os dados de expressão gênica são corretamente representados pelo modelo. A partir da tabela de transição de estado pode-se determinar uma função booleana para cada gene que descreve a sua expressão a partir da relação com os outros genes. Colocando-se uma conexão entre cada gene de entrada e de saída da regra, a estrutura da rede pode ser determinada, representando a interação entre todos os genes.

Devido à pouca quantidade de dados de expressão gênica geralmente disponíveis, o uso de Redes Booleanas se faz interessante pois, como modelo discreto, precisa de menos dados para se realizar a inferência de GRNs fornecendo uma abordagem simples e de fácil interpretação. Porém, este modelo sofre com o crescimento exponencial de estados booleanos. Também é incapaz de lidar com dados incompletos ou inconsistentes, que são muito comuns (HECKER; LAMBECK; TOEPFER, 2009; LÄHDESMÄKI; SHMULEVICH; YLI-HARJA, 2003).

\subsection{REDES BAYESIANAS}

Rede Bayesiana (RB) é um modelo de rede probabilístico e estocástico definido por um grafo direcionado acíclico (GDA). Métodos (FRIEDMAN et al., 2000; YU et al., 2004; VIGNES et al., 2011) baseados neste modelo são capazes de modelar diversas características dos processos de regulação gênica como: aleatoriedade, ruído, relações de causalidade e dependência entre os genes. Os valores de expressão de um gene são descritos por variáveis aleatórias seguindo distribuições de probabilidade (YU et al., 2004). Uma deficiência deste modelo é não poder representar redes cíclicas.

Para se realizar a inferência da estrutura de uma RB, primeiramente define-se um GDA como candidato. Essa estimativa pode ser uma rede vazia, uma rede completa, uma rede aleatória ou um modelo construído com conhecimento obtido a priori. Determina-se então os parâmetros do modelo: dado o grafo e os dados de treinamento, 
encontra-se as melhores probabilidades condicionais para cada nó. Uma função de pontuação é aplicada para cada GDA candidato, quanto melhor o modelo aprendido representar os dados de treinamento, maior a sua pontuação. $O$ modelo com maior pontuação é selecionado.

Testar todas as combinações de interação não é eficiente pois o número de GDAs possíveis aumenta de forma super-exponencial dependendo do número de genes analisados. Algoritmos de busca são utilizados para explorar o espaço de soluções possíveis. Pode-se usar algoritmos de busca local, nos quais a vizinhança será pela remoção de arestas, adição de arestas ou inversão do sentido da aresta. Pode-se também reduzir essa complexidade para polinomial caso o número de nós pais seja limitado. Alguns algoritmos de busca exploram as propriedades hierárquicas dos grafos para diminuir o espaço de busca; porém o espaço de busca ainda continuará sendo pelo menos exponencial. Uma solução para o problema é restringir o espaço de busca utilizando-se informação biológica adicional (HECKER; LAMBECK; TOEPFER, 2009).

\subsection{MODELO GRÁFICO GAUSSIANO}

O Modelo Gráfico Gaussiano (GGM do inglês Gaussian Graphical Model) se baseia em uma abordagem estatística, onde um grafo probabilístico representa a interação entre os genes através de arestas não direcionadas. Este modelo é parecido com as Redes Bayesianas, representando cada gene com relações de independência condicional, porém não é capaz de inferir relações de causalidade. GGMs descrevem a GRN usando um gráfico probabilístico não direcionado que permite distinguir interações diretas de interações indiretas, provendo relações de independência condicional entre cada par de genes (HACHE; LEHRACH; HERWIG, 2009).

O método GeneNet (SCHÄFER; STRIMMER, 2005) implementa um algoritmo de aprendizagem específico que permite estimar GGMs a partir de dados contendo poucas amostras e muitas variáveis. Ele assume que os dados têm uma distribuição normal multivariada. A matriz de correlação parcial, $r_{i j}^{X}$ está relacionada com o inverso da matriz de covariância $C$. Sendo assim, inverte-se a matriz de covariânciae as correlações parciais podem ser determinados como:

$$
r_{i j}^{X}=-\frac{C_{i j}^{-1}}{\sqrt{C_{i i}^{-1} C_{j j}^{-1}}} .
$$

No último passo um teste de significância estatística para cada correlação parcial que não seja igual a zero. 


\subsection{REDES DE CORRELAÇÃO}

Métodos baseados em correlação (CARTER et al., 2004; ZHANG; HORVATH, 2005; LANGFELDER; HORVATH, 2008; LIU, 2015) fornecem uma abordagem simples e intuitiva para a construção de redes. Uma conexão entre dois nós da rede indica que a correlação nos níveis de expressão dos dois genes representa uma interação regulatória. Redes de correlação são representadas por um grafo não direcionado onde os vértices contêm pesos que representam o coeficiente de correlação dentro do intervalo $[-1,1]$. Um coeficiente positivo indica uma relação de ativação e o coeficiente negativo, uma relação de inibição (WANG; HAIYANHUANG, 2014).

A simplicidade e o baixo custo computacional são as principais vantagens desses métodos. Como requerem baixa quantidade de amostras, são ideais para a inferência de grandes redes. Como desvantagem, geram modelos estáticos, não levam em conta o fato de múltiplos genes poderem participar no processo de regulação e não modelam relações de causalidade.

\subsubsection{WGCNA}

O método WGCNA (Weighted Gene Co-Expression Network Analysis) (ZHANG; HORVATH, 2005) é um método baseado em correlação que faz uso de uma abordagem estatística onde uma GRN é representada por uma matriz de adjacência $A=\left[a_{i j}\right]$ que codifica a conexão entre os pares de genes $i$ e $j$. Uma função de adjacência é utilizada para se obter a medida de correlação que indica a conexão entre os nós. Dependendo da função de limiar aplicada, a conexão é representada de forma binária, 0,1 , ou com pesos definidos no intervalo $[0,1]$. O método implementa tanto redes com pesos como rede sem pesos associados às arestas.

A Figura 8 apresenta o framework utilizado pelo método WGCNA (ZHANG; HORVATH, 2005) e seus passos são descritos a seguir.

A correlação de Pearson mede o grau da correlação entre dois genes assumindo apenas valores entre -1 e 1 . Se igual a 1 , significa que há uma correlação forte entre dois genes analisados. Se aumenta a expressão de um gene também aumenta do outro. Se -1, significa que há uma correlação inversa, ou seja, enquanto uma das variáveis aumenta a outra diminui. $E$ se for 0 , significa que não há correlação entre os genes (KADARMIDEEN; WATSON-HAIGH, 2012). A correlação de Pearson é definida por:

$$
A\left(G_{i}, G_{j}\right)=\operatorname{cor}\left(G_{i}, G_{j}\right)=\frac{1}{T} \sum_{l=1}^{T}\left(\frac{x_{i l}-\bar{x}_{i}}{\sigma_{i}}\right)\left(\frac{\left.x_{j l}-\bar{x}_{j}\right)}{\sigma_{j}}\right),
$$

onde $\bar{x}_{i}$ e $\bar{x}_{j}$ representam as médias dos níveis de expressão dos vetores dos genes amostrados $G_{i}$ e $G_{j}$ e $\sigma_{i}$ e $\sigma_{j}$, o desvio padrão; $A\left(G_{i}, G_{j}\right)$ é a matriz de adjacência 

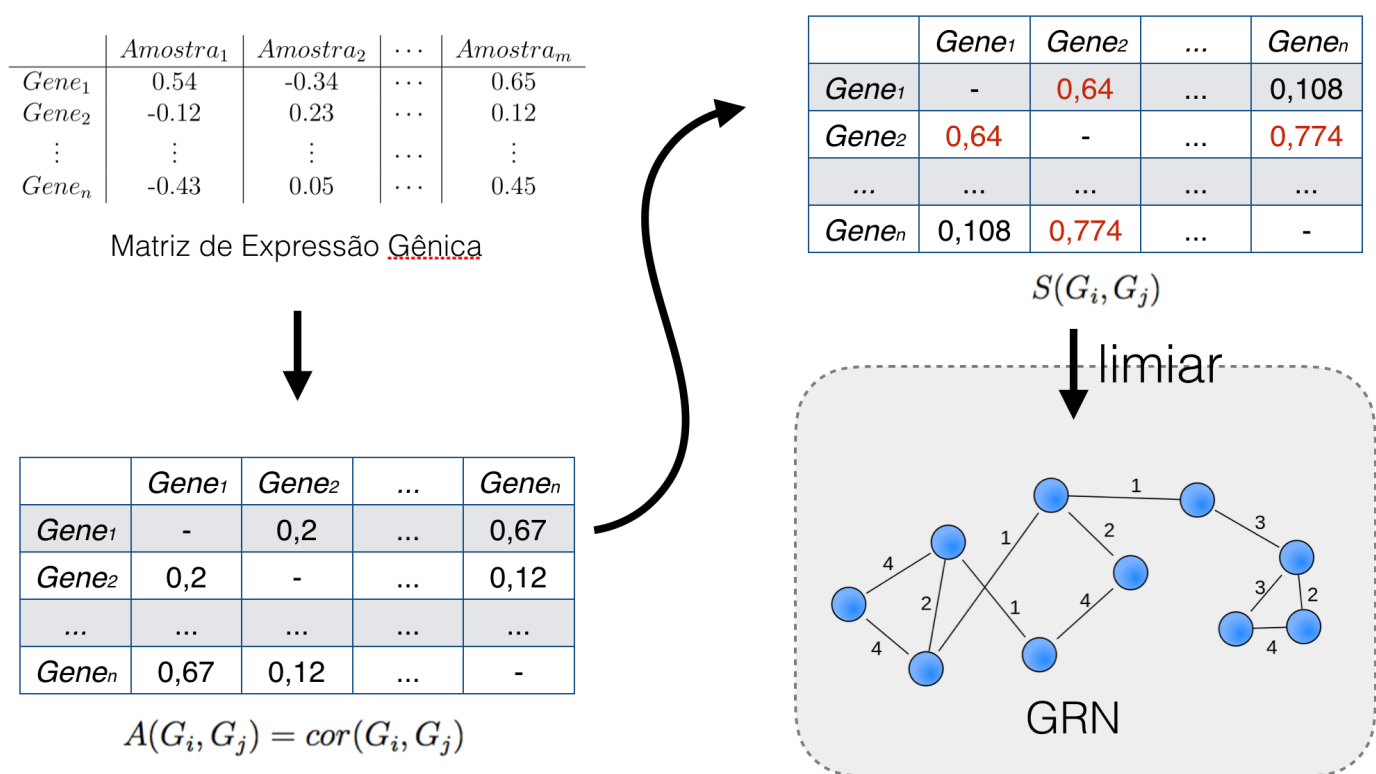

Figura 8 - Framework utilizado pelo método WGCNA.

resultante pela aplicação da correlação de Pearson nos vetores $G_{i}=\left(x_{i 1}, x_{i 2}, \ldots, x_{i T}\right)$ e $\left.G_{j}=\left(x_{j 1}, x_{j 2}, \ldots, x_{j T}\right)\right)$ que descrevem os respectivos valores das intensidades de expressão das amostras $T$ dos genes.

É importante observar que, quando uma medida de distância é utilizada para o cálculo das similaridades entre os genes, tem-se na verdade o oposto da similaridade (dissimilaridade), pois quanto maior o índice calculado (maior distância), menor o grau de correlação entre os genes envolvidos no cálculo, e quanto menor a distância, maior a similaridade. Desse modo, para obter a similaridade por meio de medidas de distância é necessário calcular o seu complemento:

$$
S\left(G_{i}, G_{j}\right)=1-\left|A\left(G_{i}, G_{j}\right)\right|^{\beta},
$$

onde $S\left(G_{i}, G_{j}\right)$ representa a similaridade entre os vetores $G_{i}$ e $G_{j}$ aplicada para cada par de genes. O WGCNA enfatiza valores altos de correlação, suavizando o limiar através da constante $\beta$ e do módulo aplicado na matriz de adjacência, isso garante a obtenção de distâncias positivas entre os pares de genes (METZ, 2006).

\subsection{REDES DE RELEVÂNCIA}

Métodos baseados em Redes de Relevância (BUTTE; KOHANE, 2000) utilizam uma abordagem estática para identificar a similaridade ou dissimilaridade entre os genes através dos seus perfis de expressão gênica. Esses métodos não utilizam um 
modelo de regulação gênica específico e suas redes são representadas por grafos não-direcionados (HECKER; LAMBECK; TOEPFER, 2009).

As medidas de expressão gênica em diferentes intervalos de tempo são consideradas independentes, ignorando sua dependência temporal nos perfis de expressão gênica. Estes métodos são parecidos com os métodos baseados em correlação, porém fazem uso de Informação Mútua para descobrir a interação entre os genes. Um limiar é aplicado para determinar apenas as interações mais relevantes entre os genes. Sua vantagem sobre os métodos baseados em correlação está em identificar relações não lineares entre as variáveis. Sua desvantagem está em não deixar claras as relações de ativação e inibição, pois gera redes com conexões sem direção (MADHAMSHETTIWAR et al., 2012). Além disso, assume-se uma relação de independência estatística de cada amostra de dados, ou seja, em uma série temporal os dados em cada passo são tratados como independentes, ignorando a dependência temporal entre os passos (HACHE; LEHRACH; HERWIG, 2009).

Inicialmente a correlação é calculada para um par de genes $\left(G_{i}, G_{j}\right)$ utilizando-se seus vetores de medidas das diversas amostras ou experimentos. Várias medidas de correlação existem como, por exemplo, a Informação Mútua:

$$
I\left(G_{i}, G_{j}\right)=H\left(G_{i}\right)+H\left(G_{j}\right)-H\left(G_{i}, G_{j}\right),
$$

onde $H$ é a entropia de Shannon de uma variável aleatória definida por:

$$
H\left(G_{i}\right)=-\sum_{z \in Z} P\left(G_{i}=z\right) \log P\left(G_{i}=z\right)
$$

onde $Z$ é o conjunto de todos os valores possíveis de $G_{i}$ e log é o logaritmo na base 2 .

Enquanto a correlação de Pearson (Equação 3.2) indica uma relação linear entre os genes, a Informação Mútua é capaz de detectar relações não lineares. Assume-se que um valor de correlação não zero para todas as medições indica uma relação biológica entre os genes correspondentes. Porém, a correlação não captura o efeito combinado de diversas regulações (HACHE; LEHRACH; HERWIG, 2009).

A medida de correlação calculada para todos os pares de genes geralmente não é zero devido ao ruído que existe entre as conexões dos genes na GRN. Mesmo removendo-se as conexões irrelevantes entre os genes, ainda assim restariam muitas conexões. Um valor de correlação acima de zero entre dois genes pode ser considerado como uma interação direta ou indireta, e até mesmo regulação de fatores de transcrição em comum. Dessa forma, interações diretas e indiretas devem ser identificadas pelo método, e em um segundo estágio tenta-se remover as conexões que representam relações indiretas (HACHE; LEHRACH; HERWIG, 2009). 


\subsubsection{CLR}

O método CLR (Context Likelihood of Relatedness) (FAITH et al., 2007) calcula a informação mútua (IM) para cada par de genes e deriva uma pontuação relacionada com a distribuição empírica dos valores de IM. Em vez de considerar a IM $I\left(X_{i}, X_{j}\right)$ entre os genes $X_{i}$ e $X_{j}$, o método considera o score $z_{i j}=\sqrt{z_{i}^{2}+z_{j}^{2}}$, onde $z_{i}$ é definida como

$$
z_{i}=\max \left(0, \frac{I\left(X_{i}, X_{j}\right)-\mu_{i}}{\sigma_{i}}\right),
$$

onde $\mu_{i}$ e $\sigma_{i}$ são a média e o desvio padrão da distribuição empírica dos valores de $\operatorname{IM} I\left(X_{i}, X_{k}\right), k=1, \ldots, n$. O método CLR foi usado por (MEYER et al., 2007) para na inferência da GRN do organismo Escherichia coli.

\subsubsection{MRNET}

MRNET é um método para que realiza uma série de seleções de características utilizando o método Relevância Máxima/Redundância Mínima (MRMR) (MEYER et al., 2007), em que cada gene $X_{i}$ desempenha o papel de saída esperada $Y$. O método classifica os variáveis de entrada definindo $V$ de acordo com a pontuação $s_{j}=u_{j}-r_{j}$. O termo de relevância $u_{j}=I\left(X_{j} ; Y\right)$ é a informação mútua de $X_{j}$ com a variável alvo $Y$ e o termo redundância

$$
r_{j}=\frac{1}{|S|} \sum_{X_{k} \in S} I\left(X_{j} ; X_{k}\right)
$$

mede a redundância média de $X_{j}$ para cada variável já selecionada $X_{k} \in S$. O processo de seleção é repetido para cada gene alvo, atribuindo $Y=X_{i}$ e $V=X \backslash X_{i}$ onde $X$ é o nível de expressão de todos os genes. Em seguida, ele calcula e seleciona a pontuação máxima $X_{j}^{M R M R}$

$$
X_{j}^{M R M R}=\arg \max _{X_{j} \in V \backslash S}\left(s_{j}\right)
$$

para cada par de genes $\left(X_{i}, X_{j}\right)$. Uma rede pode ser gerada removendo todas as arestas com pontuação menor que um dado limiar (MEYER et al., 2007).

\subsection{DISCUSSÃO}

A literatura sobre o tema é vasta, apresentando uma grande variedade de métodos de inferência e métricas de avaliação. Apesar dos modelos de arquitetura basearem-se 
em diferentes abordagens matemáticas, o resultado final de todos os métodos pode ser interpretado como uma rede de interação de genes.

A Figura 9 apresenta quatro níveis de informação que podem ser extraídas de uma tabela de expressão gênica através da inferência de redes. A partir dos dados de expressão gênica, a inferência na Figura 9 (a) determina quando existe uma relação de regulação entre $G 1$ e $G 2$. Quando se identifica uma regulação do TF de $G 1$ para G2, o nível de informação descrito na inferência da Figura 9 (b) determina a direção da aresta e a relação de causalidade na rede de regulação. A inferência da Figura 9 (c) representa os casos em que é possível inferir se um TF de G1 é capaz de ativar ou inibir $G 2$. Quando é possível identificar a forma de regulação entre dois genes, a representação da Figura 9 (d) é utilizada para mostrar o peso regulatório entre $G 1$ e $G 2$. A inferência na Figura 9 (a) mostra apenas a reconstrução das interações regulatórias, enquanto os demais níveis fornecem mais detalhes como quais genes são reguladores e quais são alvos, ativação e inibição e a força de regulação entre eles (LIU, 2015).

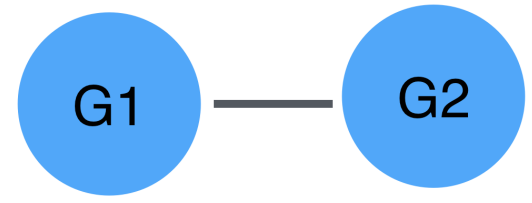

(a) Nível 1: Relações de Regulação

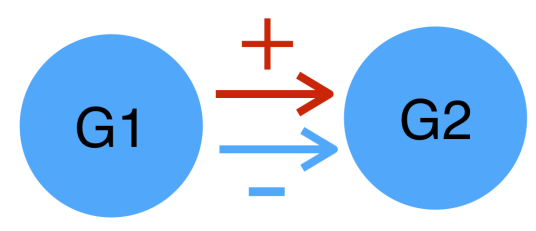

(c) Nível 3: Ativação ou Inibição

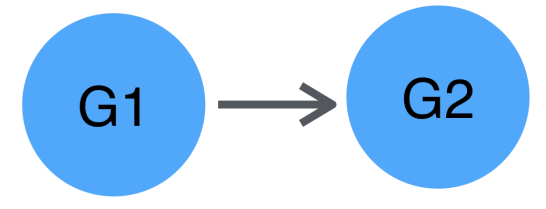

(b) Nível 2: Quem Regula

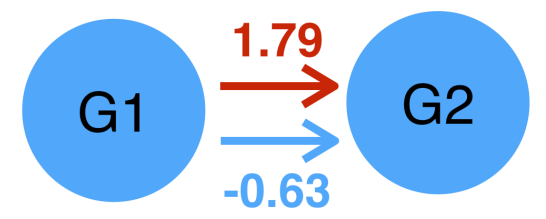

(d) Nível 4: Peso de Regulação

Figura 9 - Os quatro níveis de informação dos parâmetros regulatórios que podem ser determinados por técnicas de inferência de rede. Os métodos tratam da questão regulatória em um dos níveis ou de níveis combinados. Adaptado de (LIU, 2015).

A Tabela 3 apresenta uma comparação das propriedades dos modelos de inferência descritos nas seções anteriores. A escolha de um método de inferência deve basear-se nos tipos de dados disponíveis. Quando a quantidade de genes a serem analisados é pequena, Redes Bayesianas e Redes Booleanas são modelos mais adequados por modelarem relações de causalidade entre os genes e outras características de redes biológicas. Quando a quantidade de dados for muito grande, métodos baseados em Correlação, Redes de Relevância e Modelo Gráfico Gaussiano são mais adequados 
por serem computacionalmente mais eficientes.

Tabela 3 - Comparação das propriedades dos modelos apresentados. São classificados como Estáticos (E) ou Dinâmicos (D), Estocásticos (E) ou Determinísticos (D), Discretos (D) ou Contínuos (C) e de acordo com o nível de informação contida no modelo (Níveis apresentados na Figura 9.

\begin{tabular}{c|c|c|c|c} 
Modelo & $\begin{array}{c}\text { Estático/ } \\
\text { Dinâmico }\end{array}$ & $\begin{array}{c}\text { Estocástico/ } \\
\text { Determinístico }\end{array}$ & $\begin{array}{c}\text { Discreto/ } \\
\text { Contínuo }\end{array}$ & Nível de Informação \\
\hline $\begin{array}{c}\text { Redes } \\
\text { Booleanas }\end{array}$ & D & D & D & Nível 3 \\
\hline $\begin{array}{c}\text { Redes } \\
\text { Bayesianas }\end{array}$ & E/D & E & D/C & Nível 3 \\
\hline $\begin{array}{c}\text { Redes de } \\
\text { Correlação }\end{array}$ & E & D & C & Nível 1 \\
\hline $\begin{array}{c}\text { Redes de } \\
\text { Relevância }\end{array}$ & E & D & C & Nível 1 \\
\hline GGM & E & E & C & Nível 1
\end{tabular}

Modelos estáticos são utilizados para o estudo da regulação gênica quando se têm disponíveis dados de expressão estacionários coletados de diferentes fontes, enquanto modelos dinâmicos geralmente focam em elucidar os mecanismos de regulação através da modelagem de séries temporais, dada uma determinada condição. Dados de expressão gênica baseados em séries temporais são capazes de fornecer uma visão mais completa da dinâmica do sistema de regulação, porém dados estacionários estão disponíveis em maior quantidade e também são mais fáceis de coletar a partir de uma variedade de condições experimentais.

Os modelos estocásticos são capazes de representar melhor os sistemas de regulação pois conseguem lidar melhor com a incerteza presente no sistema devido a introdução de ruído nos dados de expressão gênica, enquanto os modelos determinísticos tratam o ruído como se fosse a expressão de um gene, devendo-se passar por uma fase de pós-processamento para eliminar as conexões da rede que foram adicionadas devido ao ruído.

Os modelos discretos consideram que cada gene possui um número finito de estados possíveis, enquanto os modelos contínuos consideram que os genes possuem valores reais de expressão.

O grafo gerado por cada modelo pode ser definido como direcionado ou nãodirecionado. Enquanto os grafos direcionados são capazes de representar as relações de causalidade entre os genes, ou seja, qual gene é responsável pela expressão ou inibição de outro gene, os grafos não direcionados não são capazes de capturar esta característica. 
É necessário ressaltar que deve-se definir de forma clara o problema para que se possa escolher o melhor método a ser aplicado. Nem todos os modelos funcionam perfeitamente para qualquer situação. Por exemplo, se o interesse não é identificar a concentração de diferentes elementos nas redes, mas apenas identificar padrões de comportamento do sistema no estado estacionário, pode-se utilizar Redes Booleanas que fornecem uma abordagem mais simplificada para o problema. O princípio lógico da Navalha de Occam (NEEDHAM et al., 2007) é aplicado aqui, ou seja, a explicação de qualquer fenômeno deve seguir apenas as premissas necessárias para sua explicação, eliminando quaisquer outras que não causem diferenças nas predições de hipóteses.

Cada método de inferência requer uma quantidade diferente de dados. Os dados disponíveis de expressão gênica estão na forma de séries temporais ou são estacionários. Séries temporais possuem a vantagem de serem capazes de identificar relações de causalidade (D'HAESELEER; LIANG; SOMOGYI, 2000). A Tabela 4 apresenta a quantidade de dados necessários para se inferir uma rede contendo $N$ genes, dependendo do modelo de inferência escolhido. Maiores detalhes sobre os dados necessários para cada modelo podem ser encontrados em (D'HAESELEER; LIANG; SOMOGY), 2000).

Tabela 4 - Dados necessários para diferentes métodos de inferência de GRNs, para redes contendo $N$ genes e conectividade $K$. Adaptado de Alakwaa (2014).

\begin{tabular}{l|l} 
Modelo & Dados Necessários \\
\hline Booleano totalmente conectado & $2 N$ \\
Booleano com conectividade $K$ & $2_{K}(K+\log (N))$ \\
Continuo totalmente conectado & $N+1$ \\
Continuo com conectividade $K$ & $K \log (N / K)$ \\
Correlação & $\log (N)$
\end{tabular}

Ainda existem problemas a serem explorados nessa área de estudo. A falta de dados de expressão gênica restringe o uso dos métodos de inferência, podendo-se questionar a qualidade das GRNs inferidas. Enfrenta-se também a complexidade na inferência devido a alta dimensionalidade de dados, fazendo com que o número de parâmetros dos modelos cresça exponencialmente, dificultando o processo de inferência devido a limitações computacionais e estatísticas (CHAl et al., 2014). Ainda, para que os métodos de inferência possam melhor ajustar os modelos, diversos dados de expressão com sua respectiva rede correta deveriam estar disponíveis. 


\section{METODOLOGIA DE AVALIAÇÃO DE DESEMPENHO}

Este Capítulo apresenta o arcabouço metodológico utilizado nesta pesquisa e uma revisão das principais métricas utilizadas na avaliação da qualidade de redes inferidas e uma discussão sobre elas.

Apesar da grande quantidade de métodos desenvolvidos para a inferência de GRNs, ainda se entende pouco sobre suas qualidades, fraquezas e desempenho. Isso deve-se principalmente à dificuldade de se avaliar os métodos, pois raramente é possível validar sistematicamente a inferência de interações a partir de dados reais in vivo. A Figura 10 apresenta um diagrama mostrando a dificuldade em se validar as redes geradas a partir de dados de expressão gênica reais, pois a estrutura da rede não é previamente conhecida.

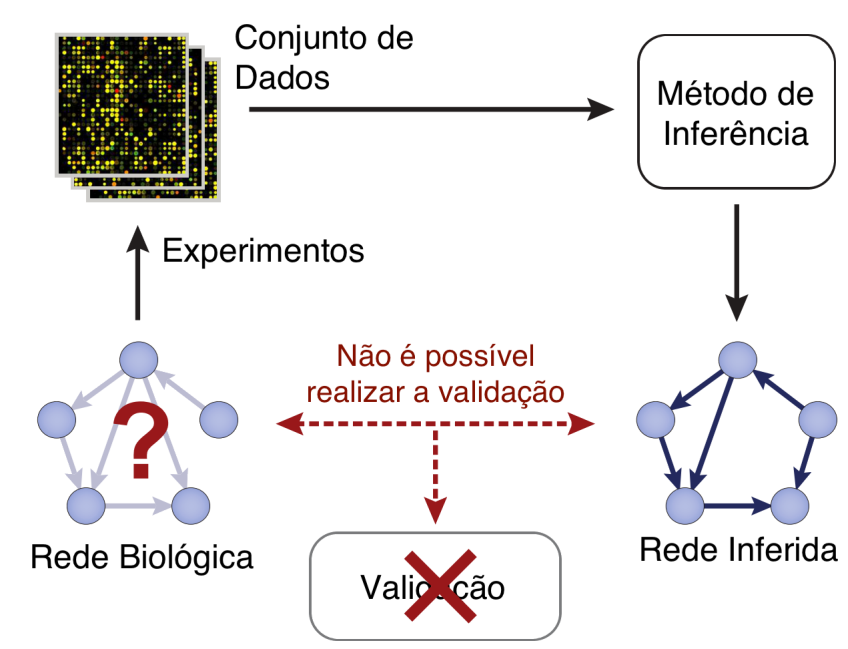

Figura 10 - Geralmente não se conhece a estrutura da rede de um sistema regulatório real, impedindo a avaliação dos métodos aplicados para sua inferência. Adaptado de Marbach et al. (2009).

Uma abordagem para se analisar e buscar o entendimento das GRNs é utilizar dados simulados (in silico) através de uma metodologia chamada de biologia sintética, comparando-se os modelos inferidos a partir dos dados simulados. A metodologia de análise computacional dos métodos de inferência de GRNs realizada neste trabalho segue a proposta apresentada no diagrama da Figura 11. A avaliação sistemática e validação dos métodos de inferência de GRNs torna-se mais fácil e confiável utilizandose dados simulados, uma vez que neles tem-se uma medida de referência correta, denominada Padrão Ouro, para a avaliação das GRNs geradas.

A necessidade de se utilizar dados simulados deve-se ao fato de todos os aspectos da rede e dos experimentos estarem sob controle, permitindo a caracterização dos 


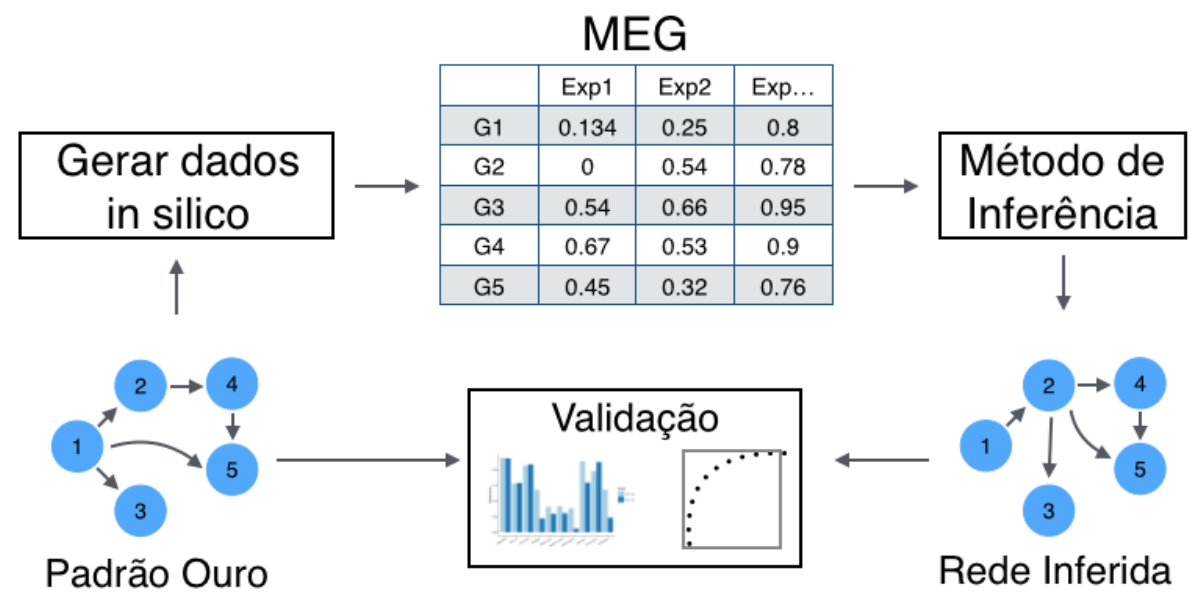

Figura 11 - Diagrama descrevendo as fases da análise computacional e avaliação de métodos de inferência de GRNs. Dado um Padrão Ouro, dados de expressão gênica são gerados, os quais são utilizados por diferentes métodos de inferência, gerando GRNs, os quais são comparados e avaliados com relação ao Padrão Ouro.

métodos de inferência de acordo com o tipo de dados, níveis de ruído e desempenho de inferência. Esta metodologia permite investigar o efeito do tamanho dos dados e variáveis ocultas na inferência de GRNs (MARBACH et al., 2009). Gerar dados simulados para validação de métodos de inferência já foi explorado por diversos autores (HACHE; LEHRACH; HERWIG, 2009; HECKER; LAMBECK; TOEPFER, 2009; LOPES; JR; COSTA, 2011; MARBACH et al., 2012; MENDOZA, 2014).

\subsection{MÉTRICAS DE AVALIAÇÃO}

As métricas de avaliação indicam o quanto a GRN inferida é similar ao Padrão Ouro fornecido. Pode-se identificar na rede inferida os genes que corretamente regulam outros genes identificando o número de vértices presentes no Padrão Ouro e também presentes na rede inferida. Esta avaliação é realizada utilizando-se a lista de adjacência apresentada na Figura 5(c) do Capítulo 2

A lista de adjacência do Padrão Ouro, que é fornecida, possui um total de $P=R+N$ interações regulatórias, sendo $R$ a classe das interações que possuem aresta entre o gene regulador e o gene alvo, ou seja valores 1 (ativação) ou -1 (inibição) na lista de adjacência. $\mathrm{E} N$, a classe das interações que não possuem arestas entre os genes, ou seja, valor 0 na lista de adjacência. A inferência da rede é dada pela lista de interações $P I=R I+N I$, ordenada de forma que os elementos no topo sejam aqueles com maior grau de confiança na inferência, onde $R I$ é a classe das interações regulatórias entre o gene regulador e gene alvo e NI a classe dos genes reguladores e alvos sem 
interação.

Pode-se então comparar os elementos de $P$ e $P I$ para se descobrir quais interações foram corretamente inferidas: interações regulatórias de ativação ou inibição corretamente inferidas $(T P)$ e incorretamente inferidas $(F P)$; interações regulatórias corretamente não inferidas ( $T N$ ), ou seja, quando existe ausência de interação (valor 0) no Padrão Ouro e na rede inferida, e, as interações incorretamente não inferidas $(F N)$, ou seja, quando existe uma interação regulatória no Padrão Ouro (1 ou -1) que está ausente na rede inferida (0). Estes valores podem ser facilmente identificados através de uma Matriz de Confusão (Tabela 5), frequentemente utilizada para avaliar classificadores binários. Nessa Tabela, 1 indica a presença de uma interação regulatória de ativação ou inibição e 0 a ausência de interação.

Tabela 5 - Matriz de Confusão.

\begin{tabular}{c|ccc} 
& \multicolumn{3}{c}{ Rede Inferida } \\
& & 1 & 0 \\
\cline { 2 - 4 } Padrão Ouro & 1 & TP & FN \\
& 0 & FP & TN
\end{tabular}

A Figura 12 apresenta uma comparação de uma rede Padrão Ouro com a GRN inferida e a relação entre suas arestas, bem como a matriz de adjacência indicando as interações regulatórias entre os genes.

Padrão Ouro

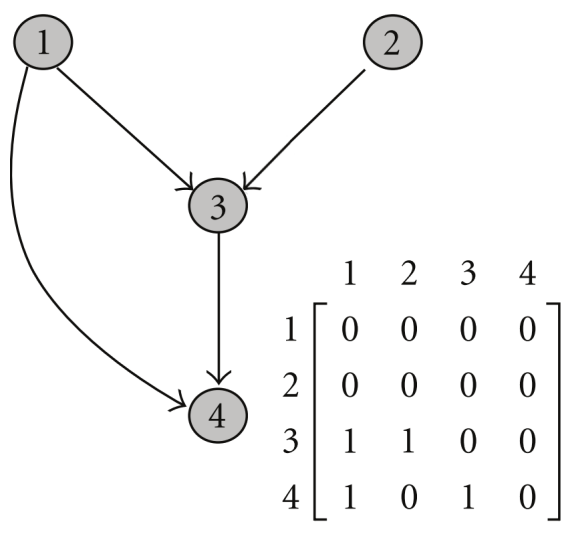

(a)
Rede Inferida

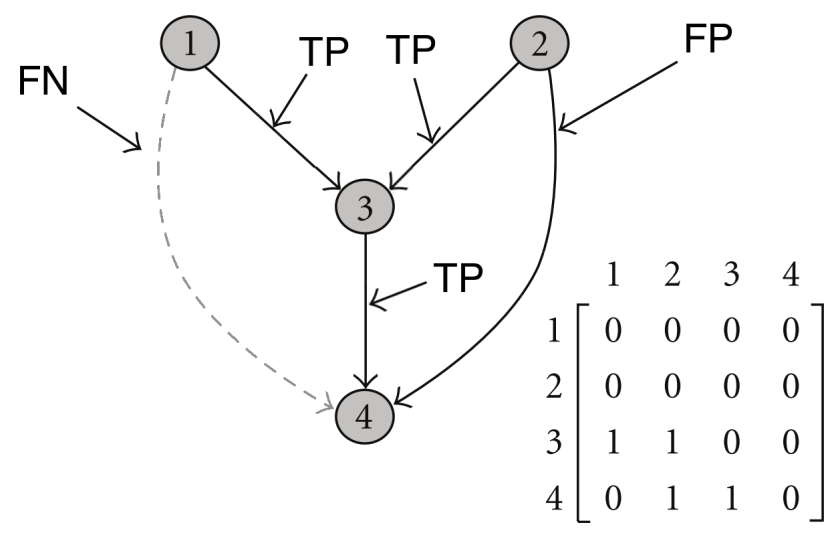

(b)

Figura 12 - Comparação entre o Padrão Ouro (a) e uma GRN inferida (b) e suas respectivas matrizes de adjacência. Adaptado de Hecker, Lambeck e Toepfer (2009).

Nesta Figura, $P$ é representada pela rede da Figura 12(a) e $P I$ pela rede da Figura 12(b). Na matriz de adjacência da Figura 12(b) $P I_{24}$ são interações incorretamente 
inferidas $(F P), P I_{13}, P I_{23}$ e $P I_{34}$ são interações corretamente inferidas (TP), $P I_{14}$ é uma interação incorretamente não inferida $(F N)$. As demais interações representadas na matriz, com valor 0 , indicam interações regulatórias corretamente não inferidas $(T N)$.

Diversos autores utilizam estes números para gerar métricas para realizar a avaliação de modelos de GRN (FRIEDMAN et al., 2000; HACHE; LEHRACH; HERWIG, 2009; MENDOZA; BAZZAN, 2012; LOPES, 2011; LIU, 2015). Algumas dessas métricas são apresentadas a seguir.

A taxa de verdadeiro positivo (TPR, do inglês True Positive Rate), também chamada de Recall, representa a fração de arestas do Padrão Ouro corretamente inferidas na GRN em relação ao número de interações esperadas:

$$
\text { Recall }=T P R=\frac{T P}{T P+F N} .
$$

A taxa de falso positivo (FPR, do inglês False Positive Rate) representa a fração de arestas que não estão presentes no Padrão Ouro mas foram incorretamente inferidas na GRN:

$$
F P R=\frac{F P}{F P+T N} .
$$

Precision representa a fração de arestas corretamente inferidas dentre o total de interações inferidas:

$$
\text { Precision }=\frac{T P}{T P+F P} .
$$

Estas métricas são determinadas verificando-se o valor da conexão entre os genes gerados pelos métodos de inferência. Se o método de inferência indicar que o valor de conexão entre dois genes é alto, então assume-se que eles estão conectados.

A curva ROC (Receiver Operator Characteristic) é frequentemente utilizada para avaliação de desempenho de classificadores binários pois apresenta como a quantidade de exemplos positivos corretamente classificados varia de acordo com a quantidade de exemplos negativos incorretamente classificados. O espaço da curva ROC é definido por $T P R$ no eixo y e $F P R$ no eixo $x$, onde cada resultado de inferência ou exemplo da Matriz de Confusão representa um ponto na curva. Esta curva ajuda a definir a relação de perda e ganho entre as interações corretamente inferidas e incorretamente inferidas. A Figura 13 apresenta quatro exemplos de curva ROC.

O melhor resultado de inferência possível irá gerar um ponto no canto superior esquerdo do gráfico representando $T P R$ de $100 \%$ e $F P R$ de $0 \%$. Uma inferência 


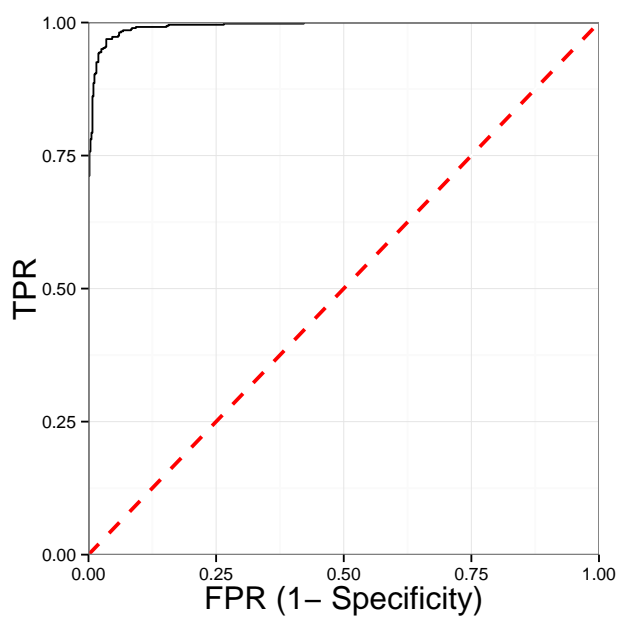

(a) Bom

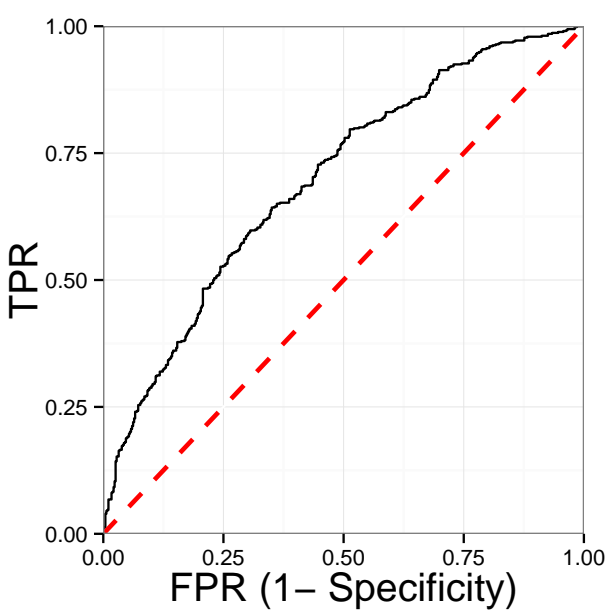

(c) Ruim

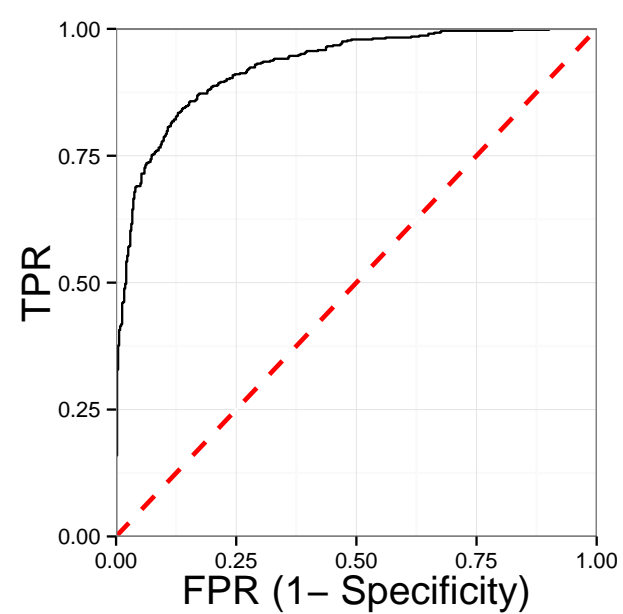

(b) Razoável

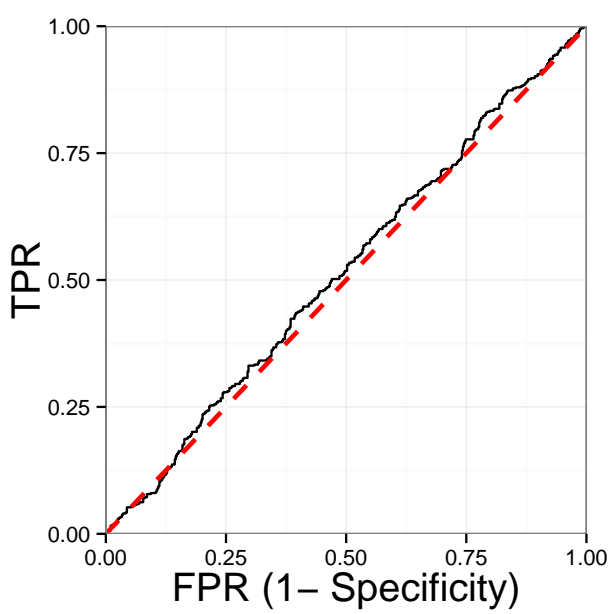

(d) Aleatório

Figura 13 - Exemplos de curvas ROC. (a) Uma curva que indica uma boa inferência. (b) Indica uma inferência razoável. (c) Indica uma inferência ruim. (d) Indica uma inferência aleatória.

aleatória irá gerar um ponto próximo à linha diagonal central. Pontos bem acima dessa diagonal representam bons resultados de inferência.

Como medida numérica utiliza-se a área abaixo da curva ROC ( $A U R O C$ ). Uma $A U R O C$ próxima de 0.5 corresponde a uma inferência aleatória, $A U R O C \leq 0.7$ corresponde a uma inferência ruim e $A U R O C \geq 0.8$, uma boa inferência (HECKER; LAMBECK; TOEPFER, 2009).

Porém, como indicado por (DAVIS; GOADRICH, 2006), a curva ROC não é uma boa métrica quando é necessário trabalhar com um conjunto de dados altamente enviesados contendo uma distribuição desigual de classes. GRNs contém muito mais exemplos negativos, ou seja, onde não existe uma interação entre dois genes do que exemplos positivos, onde existe interação. Pode-se notar isto na Figura 12 onde 
existe uma predominância de zeros. Uma GRN corretamente inferida resultaria em $T P R=1$, porém este número não representa corretamente a informação biológica já que existem muitos exemplos negativos (HECKER; LAMBECK; TOEPFER, 2009). Neste caso, indica-se o uso da curva PR (Precision-Recall curve), capaz de fornecer uma avaliação de desempenho mais informativa quando o interesse é nas classes positivas (HECKER; LAMBECK; TOEPFER, 2009; DAVIS; GOADRICH, 2006). No espaço da curva PR apresenta-se o Recall no eixo $x$ e Precision no eixo $y$, conforme ilustra a Figura 14. Este gráfico é interessante pois mostra quantas interações corretas o método é capaz de reconhecer com determinada precisão.

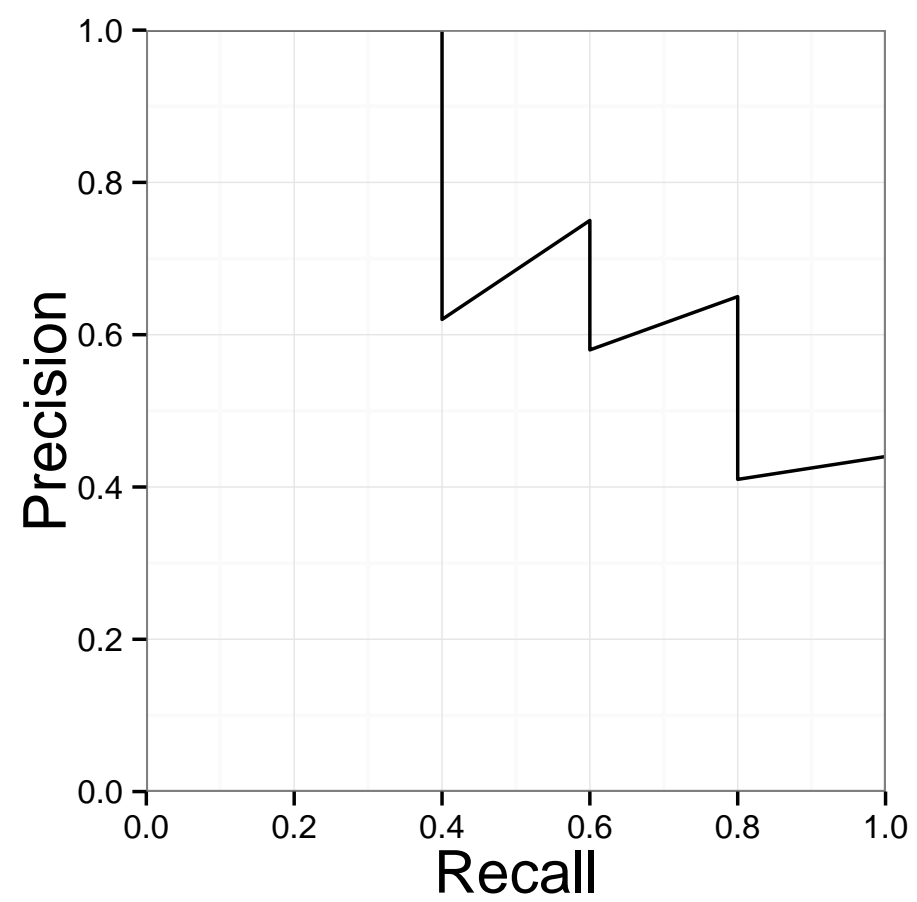

Figura 14 - Exemplo de Curva Precision-Recall. Neste exemplo percebe-se que o método pode recuperar até $40 \%$ das interações corretamente sem sacrificar a precisão, porém para recuperar $100 \%$ é necessário aceitar uma precisão próxima de $45 \%$

Pode-se extrair a área abaixo da curva PR $(A U P R)$ como um valor numérico para representar a qualidade de inferência. Quanto maior este valor, melhor a qualidade de inferência.

Algoritmos que produzem uma boa $A U R O C$ não necessariamente irão produzir uma boa $A U P R$. Apesar de um dos eixos da curva ROC e da curva PR serem iguais $(T P R=$ Recall $)$ o outro eixo é diferente. Enquanto as curvas ROC utilizam FPR, as curvas PR usam Precision. A métrica Precision é diretamente influenciada pelo desequilíbrio de classes caso exista uma grande quantidade de falso positivos $(F P)$, 
enquanto $T P R$ depende apenas de exemplos positivos. 



\section{USANDO COMITÊS PARA MELHORAR A INFERÊNCIA DE REDES GÊNICAS}

Neste Capítulo são apresentados os comitês de especialistas e os experimentos realizados. O conjunto de dados utilizado foi fornecidos pela competição DREAM5 System Genetics (PINNA et al., 2011). O experimento conduzido consiste em remover amostras dos conjuntos de dados para investigar o impacto do tamanho da amostra na qualidade das redes inferidas. Para melhorar os resultados dos experimentos, foram aplicadas técnicas de comitês de especialistas populares para agregar as redes de genes resultantes dos métodos de inferência.

O aprendizado baseado em comitês de especialistas é o processo pelo qual diversos modelos, sejam computacionais ou aplicados por especialistas, são gerados e combinados para resolver um determinado problema que envolva aprendizado. Sistemas baseados em comitês de especialistas podem ser utilizados para:

- Melhorar o desempenho, ou reduzir o espaço de busca de um determinado problema;

- Auxiliar na escolha dos melhores classificadores para um determinado problema;

- Podem ser úteis quando se está lidando com uma grande quantidade de dados com disparidade de classes (POLIKAR, 2006).

Nos mais diversos campos de conhecimento algumas decisões são tomadas a partir da opinião de uma comunidade de especialistas, ao invés de depender apenas da opinião de um único indivíduo (POLIKAR, 2006). Em Inteligência Artificial (IA), a abordagem de comitês de especialistas é usada para combinar classificadores. Estudos recentes têm mostrado que a utilização de um conjunto de classificadores geralmente produz resultados mais precisos do que levar em conta o resultado de um único classificador (WHALEN; PANDEY, 2013; MARBACH et al., 2012; MACLIN; OPITZ, 2011; POLIKAR, 2006).

Recentemente, alguns estudos têm abordado o uso de comitês de especialistas em genômica. Whalen e Pandey (2013) exploram o uso de comitês de especialistas na predição da função das proteínas e previsão de interação genética através da aplicação e combinação de alguns algoritmos de aprendizado de máquina. Eles demonstram que as abordagens apresentadas oferecem melhorias estatisticamente significativas para a inferência de GRNs.

Métodos de inferência possuem vantagens e desvantagens dependendo do contexto, o que sugere que combinando os resultados de diferentes métodos pode-se 
melhorar a inferência das redes. Mesmo que um método apresente resultados individuais melhores do que métodos combinados para uma determinada rede, deve-se notar que o desempenho desse método geralmente não é generalizado para outras redes. Dada a variação biológica entre organismos, experimentos e tecnologias utilizadas para gerar os dados, é difícil determinar com antecedência qual método vai gerar o melhor resultado de inferência (MARBACH et al., 2012). É importante notar também que alguns métodos propostos são testados com dados gerados utilizando-se o mesmo modelo matemático implementado no método, o que pode introduzir um viés tendencioso para que o método apresente os melhores resultados.

Marbach et al. (2012) exploraram o conceito de Wisdom of Crowds aplicado ao problema de inferência de GRNs, e sugerem que o conhecimento coletivo de uma comunidade pode ser maior do que o conhecimento de qualquer indivíduo sozinho. Os autores combinaram as redes inferidas das equipes participantes do desafio DREAM para a construção de uma rede comunitária, levando em conta o nível de confiança dado para cada interação e ordenando as interações pela média do nível de confiança. O estudo sugere que a combinação de métodos de inferência pode ser uma boa estratégia para melhorar a qualidade da reconstrução das GRNs, pois cada método tem diferentes pontos fortes e fracos, como descrito no Capítulo 3.

Mendoza e Bazzan (2012) realizaram um estudo comparativo entre várias técnicas de comitês de especialistas e analisaram seus desempenhos aplicados em redes booleanas probabilísticas geradas artificialmente. Os autores descobriram que os resultados dos técnicas de comitês foram mais precisos do que os individuais. Zhong e colegas (ZHONG et al., 2014) também avaliaram o desempenho de diferentes métodos de inferência estatísticos usando redes simuladas e dados de Escherichia coli. Os autores propuseram o método ENA, mostrando que pode ser utilizado para integrar GRNs construídas por métodos diferentes, produzindo redes mais precisas.

A maioria dos estudos de inferência de GRNs parte de cenários irrealistas, com grande quantidade de amostras de dados disponíveis, ou apenas um pequeno conjunto de genes presentes nas redes. No entanto, apenas alguns organismos, tais como Escherichia coli possuem grande número de amostras disponíveis.

Outro problema é que alguns estudos assumem dados binários como entrada para os seus algoritmos de inferência. Embora isso possa ajudar na investigação do comportamento global das redes de genes (SHMULEVICH et al., 2002), e na descoberta de novos modelos matemáticos e métodos, conjuntos de dados binários são propensos a perda de informações importantes devido à quantização e não capturam as perturbações ruidosas dos perfis de expressão gênica gerados pelas tecnologias de sequenciamento. 
A Tabela 6 apresenta alguns trabalhos relacionados, os métodos de inferência de redes aplicados, a fonte dos dados, número de genes e amostras presentes nos conjuntos de dados fornecidos e métricas utilizadas para avaliação.

Tabela 6 - Resumo comparativo de trabalhos relacionados, seus métodos, fonte de dados, número de genes e amostras e métricas utilizadas.

\begin{tabular}{|c|c|c|c|c|}
\hline Citação & Métodos & Dados & $\begin{array}{l}\text { \# de genes } \\
\text { e amostras }\end{array}$ & Métodos \\
\hline $\begin{array}{r}\text { Zhong } \\
\text { et al. (2014) }\end{array}$ & $\begin{array}{l}\text { BN, GeneNet, SPACE, } \\
\text { WGCNA, ARACNe }\end{array}$ & $\begin{array}{l}\text { Distribuições } \\
\text { Levedura }\end{array}$ & $\begin{array}{c}17,44,83,231,612 \text { genes } \\
20,50,100,200,500 \\
\text { e } 1000 \text { amostras }\end{array}$ & $\begin{array}{l}\text { AUROC } \\
\text { pAUROC }\end{array}$ \\
\hline $\begin{array}{r}\text { Mendoza \& } \\
\text { Bazzan (2012) }\end{array}$ & $\begin{array}{c}\text { Bayesian, Boolean, } \\
\text { ARACNe }\end{array}$ & AGN & $\begin{array}{l}30 \text { e } 50 \text { genes } \\
100 \text { amostras }\end{array}$ & AUROC \\
\hline $\begin{array}{l}\text { Marbach, D. } \\
\text { et al. (2012) }\end{array}$ & $\begin{array}{l}30 \text { métodos } \\
\text { submetidos }\end{array}$ & DREAM5 & $\begin{array}{c}1.643,4.297,5.667 \mathrm{e} \\
2.677 \text { genes } \\
805.536 \text { e } 160 \text { amostras }\end{array}$ & $\begin{array}{l}\text { AUPR } \\
\text { AUROC }\end{array}$ \\
\hline $\begin{array}{l}\text { Marbach, D. } \\
\text { et al. }(2010)\end{array}$ & $\begin{array}{l}29 \text { métodos } \\
\text { submetidos }\end{array}$ & DREAM3 & $\begin{array}{l}10,50 \text { e } 100 \text { genes } \\
50 \text { e } 100 \text { amostras }\end{array}$ & $\begin{array}{l}\text { ROC-curve } \\
\text { PR-curve }\end{array}$ \\
\hline $\begin{array}{r}\text { Madhamshettiwar } \\
\text { et al. (2012) }\end{array}$ & $\begin{array}{l}\text { MRNET, CLR, } \\
\text { WGCNA e } \\
\text { outros métodos }\end{array}$ & $\begin{array}{l}\text { DREAM3 } \\
\text { DREAM5 }\end{array}$ & $\begin{array}{l}100 \text { genes } 100 \text { amostras } \\
\text { E. coli, S. cerevisiae }\end{array}$ & AUROC \\
\hline $\begin{array}{r}\text { Hache } \\
\text { et al. (2009) }\end{array}$ & $\begin{array}{c}\text { ARACNe, ParCorA, } \\
\text { GNRevealer, Banjo, } \\
\text { LDST, GeneNet }\end{array}$ & GeNGe & $\begin{array}{c}5,10,20, \text { e } 30 \text { genes } \\
5,10,20,30 \\
\text { e } 50 \text { amostras }\end{array}$ & AUROC \\
\hline
\end{tabular}

A grande maioria dos trabalhos relacionados se baseiam em conjuntos de dados que contém muitas amostras e geralmente poucos genes. MARBACH et al. (2012) e MARBACH et al. (2010) realizando um estudo comparativo utilizando-se diversos métodos de inferência, porém os métodos não podem ser comparados um com o outro pois geram redes com diferentes níveis de detalhamento. Trabalhos como o de HACHE; LEHRACH; HERWIG (2009) utilizam poucas amostras de dados, porém também utilizam poucos genes.

\subsection{COMITÊS DE ESPECIALISTAS}

Aprendizado baseado em comitês de especialistas é o processo pelo qual diferentes resultados gerados são combinados para resolver um determinado problema. Os sistemas baseados em comitês de especialistas podem ser utilizados para melhorar o desempenho ou reduzir a vizinhança de busca de um problema de classificação, escoIhendo e combinando os melhores classificadores. Tais sistemas ajudam a melhorar a qualidade de classificação quando se lida com uma grande quantidade de dados com disparidade de classes.

Como este experimento adota métodos de inferência que resultam em valores de saída contínuos, um para cada par de genes, pode-se interpretar cada saída como uma valor de confiança dado para a possível interação de dois genes. A pontuação de confiança de muitos métodos de inferência pode ser combinada para melhorar a 
precisão da rede gênica reconstruída. A Figura 15 mostra um quadro geral de um sistema baseado em comitês de especialistas. A matriz de expressão gênica é dada como entrada para os métodos de inferência e a saída de cada algoritmo é combinada por um combinador $\mu_{j}(x)$.

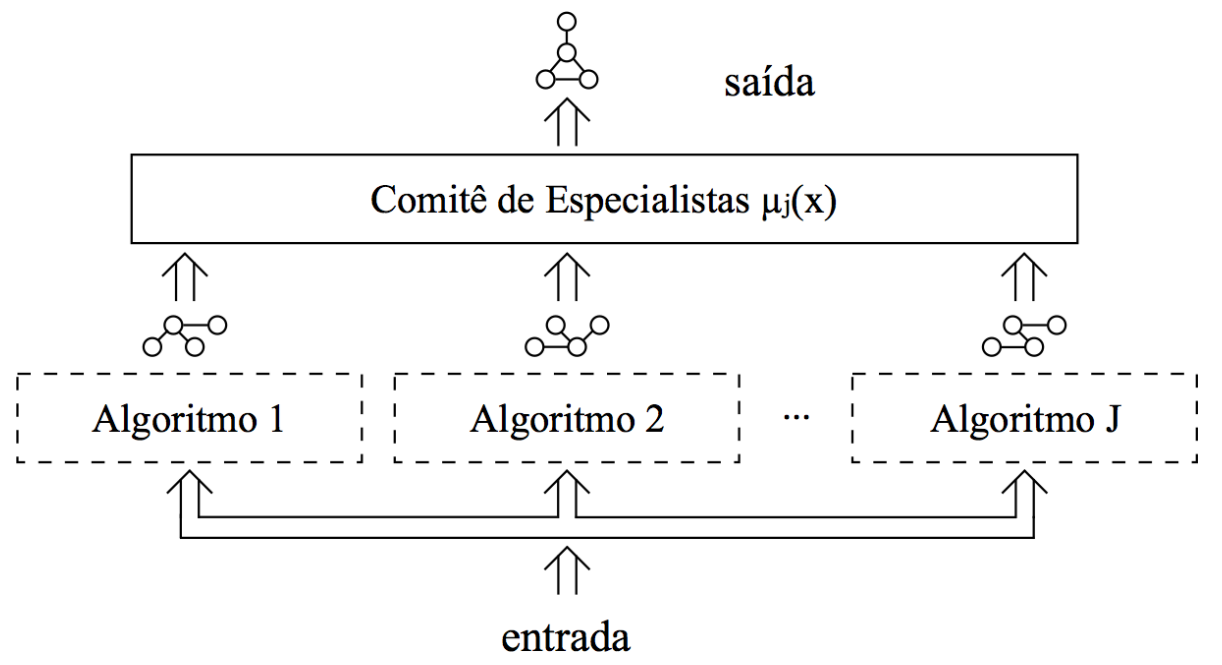

Figura 15 - Um combinador de vários métodos de inferência de GRNs. Cada algoritmo produz a sua própria representação da rede de genes, que são agregadas pelo combinador $\mu_{j}(x)$.

Combinar a saída de vários métodos de inferência é útil somente se houver discordância entre eles, uma vez que a combinação de métodos idênticos produz praticamente ganho nulo (MACLIN; OPITZ, 2011).

Existem muitas abordagens de comitês e o melhor algoritmo depende dos dados disponíveis e do problema onde é aplicado. Comitês que utilizam funções Regra do Máximo (Maximum Rule), Regra da Média (Mean Rule) e Regra da Média Ponderada (Weighted Average) são simples e mostram um desempenho consistente em problemas onde as classes são formadas por valores contínuos e a precisão dos classificadores pode ser estimada com segurança (POLIKAR, 2006).

Nas seções a seguir nós descrevemos estes algoritmos e também a abordagem Classificação pelo Produto (Rank Product) proposta por (ZHONG et al., 2014).

\subsubsection{Regra do Máximo}

Esta é uma das técnicas de comitês mais simples, tomando o máximo entre as saídas dos classificadores de acordo com a regra

$$
\mu_{j}(x)=\max _{t=1 \ldots T}\left\{d_{t, j}(x)\right\},
$$

onde $T$ é o número total de classificadores e $d_{t, j}(x) \in[0,1]$ representa o nível de confiança dado pelo classificador $t$ para a classe $\omega_{j}$ para uma data saída $x$ (POLIKAR, 
2006). Neste trabalho cada classe $\omega_{j}$ representa a presença (ou ausência) de uma aresta entre dois genes.

\subsubsection{Regra da Média}

Esta é uma técnica de comitê que usa uma função simples para calcular a contribuição total para cada interação entre os genes (classe). A escolha da classe $\omega_{j}$ é calculada obtendo-se a média de todas as saídas $j$, obtidas pelos diferentes métodos de inferência:

$$
\mu_{j}(x)=\frac{1}{T} \sum_{t=1}^{T} d_{t, j}(x),
$$

onde a classe $\omega_{j}$ com o maior $\mu_{j}(x)$ é escolhida (POLIKAR, 2006).

\subsubsection{Regra da Média Ponderada}

Esta função combina a função Regra da Média subseção 5.1.2 com votação por maioria ponderada. A votação por maioria é o algoritmo usado tradicionalmente por votação pública, onde a classe $\omega_{j}$ que recebe o maior número de votos, ganha. $\mathrm{Na}$ votação por maioria ponderada, se certos métodos são mais precisos do que outros, então podem adicionar pesos $\omega_{t}$ às suas opiniões na enquete de votação (quanto maior o peso, melhor a precisão). Na média ponderada os pesos não são aplicados nas classes de saída, mas sim na saída contínua $d_{t, j}(x)$ (POLIKAR, 2006). Esta regra é definida como:

$$
\mu_{j}(x)=\sum_{t=1}^{T} \omega_{t} d_{t, j}(x) .
$$

Os pesos $\omega_{t}$ escolhidos neste trabalham foram selecionados de forma empírica analisando-se os resultados obtidos para as métricas AUROC e AUPR descritas no Capítulo 6. Foram usados os pesos 0.9 para o GeneNet, 0.8 para o WGCNA, 0.3 para CLR e MRNET.

\subsubsection{Classificação pelo Produto}

No algoritmo de Classificação pelo Produto (do inglês Rank Product) leva-se em consideração uma competição entre as classes disponíveis, onde o valor mais baixo é atribuído à classe com maior confiança para a saída de cada classificador (ZHONG et al., 2014). Após a classificação (rank) $d_{t, j}(x)$ ser calculada para cada GRN gerada por cada método de inferência $t \in T$, calcula-se o produto de cada aresta em particular 
$\mu_{j}(x)$ utilizando-se o produto das classificações (ranks) das mesmas arestas através de todas as GRNs (através de todos os classificadores $T$ ):

$$
\mu_{j}(x)=\prod_{t=1}^{T} d_{t, j}(x) .
$$

\subsection{EXPERIMENTO}

O arcabouço experimental utilizado neste trabalho é apresentado na Figura $16 \mathrm{e}$ descrito a seguir.

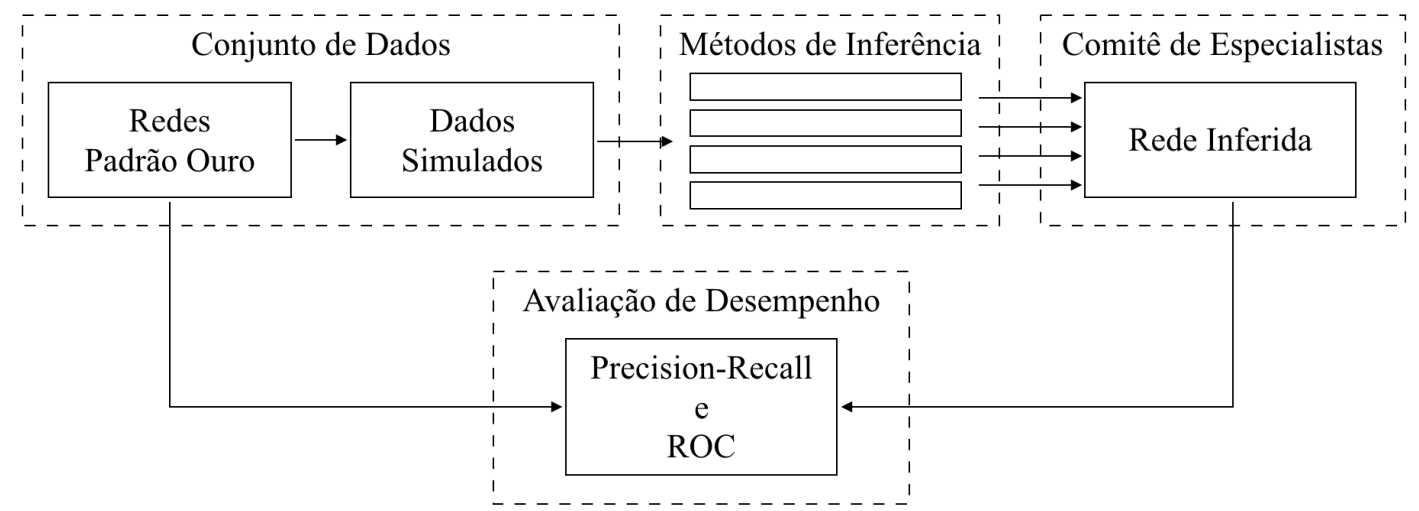

Figura 16 - Arcabouço experimental. Dados simulados do desafio DREAM5 são usados como entrada para os métodos de inferência, os métodos de inferência são aplicados e a avaliação de desempenho é realizada.

Devido à falta de uma rede Padrão Ouro determinada experimentalmente, utilizamos neste trabalho dados simulados. Entende-se que dados simulados seguem um modelo que é uma representação simplificada da realidade. Utilizou-se o conjunto de dados de referência fornecido pelo desafio DREAM5 System Genetics 1 para explorar a eficácia do arcabouço experimental proposto pois estes dados se baseiam em dados de levedura, incluindo problemas encontrados em dados reais como ruídos e outras interferências dos equipamentos utilizados. Os conjuntos de dados simulados foram gerados pelo software SysGenSIM (PINNA et al., 2011) disponível no site do desafio. Esta ferramenta tem por objetivo auxiliar na compreensão de metodologias para inferência de GRNs, a fim de identificar quais métodos têm o melhor desempenho em determinadas condições como tamanho da população, distâncias dos marcadores, alta ou baixa hereditariedade e o tamanho da rede. A dinâmica da expressão gênica é simulada com base no estado estacionário para uma população de indivíduos utilizando-se a topologia da rede de seus genes e genótipos e um conjunto de variantes do DNA do genoma, aplicando-se uma equação diferencial ordinária não-linear.

1 Site do DREAM5 System Genetics challenge: https://www.synapse.org/\#!Synapse:syn2820440/wiki/71029 
As características de expressão gênica de estado estacionário são simuladas para uma população de indivíduos, com base numa topologia de rede e nos genótipos de indivíduos num conjunto de variantes de DNA, utilizando equações diferenciais ordinárias não lineares (ODEs). A lei de taxas utilizada pelo SysGenSIM para transcrição não é baseada em nenhum mecanismo explícito, mas apresenta duas principais características da cinética: saturação e cooperatividade. Assumi-se que a decomposição de mRNA é um processo de primeira ordem. A ODE para o gene $g$ é descrita na Equação 5.5.

$$
\frac{\mathrm{d} G_{g}}{\mathrm{~d} t}=Z_{g}^{c} \cdot V_{g} \cdot \theta_{g}^{s y n} \cdot \prod_{k}\left(1+A_{k, g} \frac{G_{k}^{h_{k, g}}}{G_{k}^{h_{k, g}}+\left(K_{k, g} / Z_{k}^{t}\right)^{h_{k, g}}}\right)-\lambda_{g} \cdot \theta_{g}^{d e g} \cdot G_{g}
$$

Onde $G_{g}$ é a concentração de mRNA do gene $g, V_{g}$ é a sua taxa de transcrição basal e $\lambda_{g}$ é a taxa de degradação. $G_{k}$ são as concentrações de mRNA de genes que têm arestas dirigidos no nó $G_{g}$. $K_{k} g$ é uma constante que representa as concentrações do gene de entrada $k$ no qual o seu efeito na taxa de transcrição do gene $g$ é metade do seu efeito máximo, $h_{k} g$ é um coeficiente de cooperatividade e $A_{k} g$ é um elemento da matriz $A$ codificando a estrutura de rede. $A_{k} g=-1$ para inibição, $A_{k} g=1$ para ativação e $A_{k} g=0$ para nenhum efeito. Os parâmetros $\theta_{g}^{\text {syn }}$ e $\theta_{g}^{\text {deg }}$ representam o ruído biológico interno não genético nas taxas de transcrição e degradação. Seus valores são amostrados a partir de distribuições normais com média 1 e desvio padrão especificados no software antes do cálculo de cada estado estacionário. $Z_{g} c$ e $Z_{k} t$ são parâmetros que incorporam efeitos de variantes de DNA. Após a geração de uma topologia de rede, as equações não lineares são formuladas de acordo com essa topologia, codificadas na matriz $A$. Os parâmetros cinéticos $V_{g}, K_{k} g, h_{k} g$ e $\lambda_{g}$ são inicializados por valores de amostragem de distribuições uniforme, gausiana ou gamma, com valores de parâmetro padrão ou especificados no software, para gerar um conjunto de valores de parâmetros base, ou seja, o "fundo genético" do organismo. A variabilidade da expressão gênica entre indivíduos na população resulta de diferentes genótipos (valores dos parâmetros $Z_{g} c$ e $Z_{k} t$ ) e flutuações biológicas adicionais (representadas pelos parâmetros de ruído $\theta_{g}^{s y n}$ e $\theta_{g}^{d e g}$ ) (PINNA et al., 2011). Para o entendimento matemático de como os dados são gerados recomenda-se a leitura do artigo (PINNA et al., 2011) e consulta do manual do software SysGenSIM2.

Redes de 1000 genes com níveis de expressão gênica no estado estacionário foram criadas usando topologia modular sem escala e as simulações foram feitas usando equações diferenciais ordinárias determinísticas (LIU; FUENTE; HOESCHELE, 2008). Os conjuntos de dados contêm perfis de expressão gênica com três tamanhos de

2 Manual do SysGenSIM disponível em http://sysgensim.sourceforge.net/wiki/index.php/SysGenSIM_manual 
amostra: 100, 300 e 999. Para cada tamanho de amostra, cinco redes diferentes, com diferentes quantidades de arestas foram simuladas.

Foram escolhidos métodos bem difundidos na literatura e com pacotes de software implementados na linguagem $R$ e que podem ser executados em qualquer computador pessoal. Estes métodos aceitam perfis de expressão como entrada e são capazes de gerar topologias contendo um grande número de genes para poucas amostras. A Tabela 7 apresenta um resumo dos métodos selecionados:

Tabela 7 - Métodos de inferência de GRNs analisados.

\begin{tabular}{|c|c|c|c|}
\hline Algoritmos & Modelo & ieferência & crição \\
\hline Ger & Modelo Grá & Schäfer e Strimmer & \\
\hline WGCNA & $\operatorname{Re}$ & Horvath (2008) & 3.4 \\
\hline CI & $\operatorname{Rec}$ & Fait & $\mathrm{cov}$ \\
\hline IRNF & Redes de Relevância & 1. 2007$)$ & \\
\hline
\end{tabular}

Os padrões-ouro fornecidos consistem numa lista de arestas com o gene de origem $v_{i}$ na primeira coluna e o gene alvo $v_{j}$ na segunda coluna. A terceira coluna se refere a presença (definido como 1) ou ausência (definido como 0 ) de interação regulamentar do gene $v_{i}$ para o gene $v_{j}$.

Como o objetivo é avaliar os algoritmos de inferência a partir de conjuntos de dados com pequeno número de amostras, também criou-se sete novos perfis de expressão gênica contendo 5, 10, 15, 20, 30, 50 e 80 amostras. Tais conjuntos de dados são subconjuntos de conjuntos de dados contendo 100 amostras.

A comparação das GRNs inferidas e o padrão ouro estão resumidas na matriz de confusão (Tabela 5). Nesta pesquisa, os resultados são avaliados utilizando a área sob a curva de Precision-Recall, $A U P R$ e a área sob a curva ROC (Receiver Operator Characteristic), $A U R O C$.

Os métodos de inferência geralmente retornam a GRN inferida como um grafo não direcionado com pesos $G N=(\mathcal{V}, \mathcal{E})$ onde $\mathcal{V}=\left\{v_{1}, \cdots, v_{n}\right\}$ são os vértices (genes) e $\mathcal{E}=\left\{\left(v_{i}, v_{j}\right): v_{i}, v_{j} \in \mathcal{V}\right\}$ é a matriz de adjacência onde $\mathcal{E}_{i j}$ é o valor de confiança dado pelo método de inferência para a interação entre $v_{i}$ e $v_{j}$.

Embora alguns métodos de inferência como CLR e MRNET retornem uma matriz de adjacência esparsa onde a maioria das interações são 0 , outros como WGCNA e GeneNet retornam um grafo com pesos associados a todas as arestas $\mathcal{E}_{i j}$. Enquanto um valor alto de $\mathcal{E}_{i j}$ expressa um valor alto de confiança que indica uma relação de regulação entre os genes $v_{i}$ e $v_{j}$, valores próximos a zero indicam que não existe nenhuma interação entre eles.

Para a avaliação dos algoritmos, o triângulo superior direito $\left(\mathcal{E}_{i j}: i<j\right)$ da matriz de adjacência da rede inferida é convertido em uma lista de adjacência ordenada onde o 
índice do gene de origem $v_{i}$ é sempre menor do que o índice do gene alvo $v_{j}$.

A lista de adjacência ordenada é comparada com a lista de adjacência do padrão ouro $\mathcal{G}$, a fim de indicar a precisão do método de inferência. A lista de adjacência do padrão ouro $\mathcal{G}_{i j}$ pode assumir os valores 1 e 0 . Se $\mathcal{G}_{i j}$ é igual a 1 , uma interação positiva verdadeira (TP) é assumida quando o método de inferência indicar um alto valor de confiança $\mathcal{E}_{i j}$. Se $\mathcal{G}_{i j}$ é igual a 0 e $\mathcal{E}_{i j}$ é alto, significa que o método de inferência retornou uma interação falso positiva (FP). Quando $\mathcal{G}_{i j}$ é 0 e $\mathcal{E}_{i j}$ é próximo de 0 , o método de inferência identificou corretamente uma interação verdadeira positiva (TN), enquanto que $\mathcal{G}_{i j}$ é 1 e $\mathcal{E}_{i j}$ próximo de 0 , o método de inferência indicou uma interação falso negativa (FN).

Depois que os métodos de inferência foram aplicados para todos os conjuntos de dados e as funções para gerar os comitês foram aplicadas, calculou-se o $A U R O C \mathrm{e}$ $A U P R$ individuais para cada uma das cinco redes geradas (cinco redes para cada tamanho de amostra). Estas pontuações indicam o desempenho dos métodos variando o limiar do valor de confiança. Para cada tamanho de amostra considerada, calculou-se a média dos cinco $A U R O C$ e $A U P R$ obtidos por cada método em um único valor. 



\section{RESULTADOS E DISCUSSÃO}

Neste Capítulo são apresentados os resultados da comparação de métodos populares aplicados na inferência de redes gênicas e o uso de comitês de especialistas. $O$ experimento mostra que a diminuição de amostras do conjunto de dados degrada drasticamente a qualidade de todos os métodos de inferência. Além disso, o experimento mostra que podemos melhorar a qualidade das redes inferidas através da aplicação de comitês.

As Figuras 17 e 18 apresentam a área sob a curva ROC ( $A U R O C)$ e a área sob a curva PR $(A U P R)$ para as redes inferidas, descrevendo os resultados para os conjuntos de dados padrões fornecidos pelo desafio DREAM5 (100, 300 e 999 amostras) e os conjuntos de dados gerados no experimento (5, 10, 15, 20, 50 e 80 amostras).

Neste trabalho tem-se como objetivos realizar uma avaliação comparativa de métodos de inferência de redes e comitês de especialistas e explorar o quanto a variação da quantidade de amostras afeta a qualidade de inferência e validar uma quantidade de amostras mínimas necessária.

Está claro que um número crescente de amostras aumenta a qualidade de inferência de todos os métodos, considerando ambos os valores de $A U R O C$ e $A U P R$. O método WGCNA apresentou os melhores valores para $A U R O C$ para o tamanho das amostras 100, 300 e 999: 0.767, 0.844 e 0.896, respectivamente. Em seguida, vem o método CLR com valores para $A U R O C$ de 0.763 , 0.842 e 0.883 , e MRNET com $0.758,0.831$ e 0.869 . O pior método na comparação para estes três tamanhos de amostra foi o GeneNet com pontuação $A U R O C$ de $0.757,0.808$ e 0.848 , o que significa que o método GeneNet identificou mais interações falso positivas do que qualquer outro método.

Os valores de $A U R O C$ obtidos por todos os métodos de inferência para pequenos conjuntos de dados foram muito semelhantes. No entanto WGCNA e GeneNet competem um com o outro: WGCNA apresenta melhores resultados para tamanhos de amostra 50 e 80 , enquanto GeneNet apresenta melhores resultados para conjuntos de dados com menos amostras. O valor de $A U R O C$ obtido por WGCNA foram 0.539 , $0.575,0.604,0.630,0.707$ e 0.750 para $5,10,15,20,50$ e 80 amostras, respectivamente. Por sua vez, os valores obtidos por $A U R O C$ GeneNet foram $0.545,0.583,0.610$, $0.633,0.705$ e 0.741 .

Para os valores de $A U P R$ percebe-se uma situação completamente diferente, onde GeneNet alcançou a melhor pontuação $A U P R$ para as redes inferidas a partir de conjuntos de dados com os tamanhos 100, 300 e 900: 0.141, 0.251 e 0.336, respectivamente. Ele é seguido por CLR, com valores $0.131,0.241$ e 0.330 , MRNET 


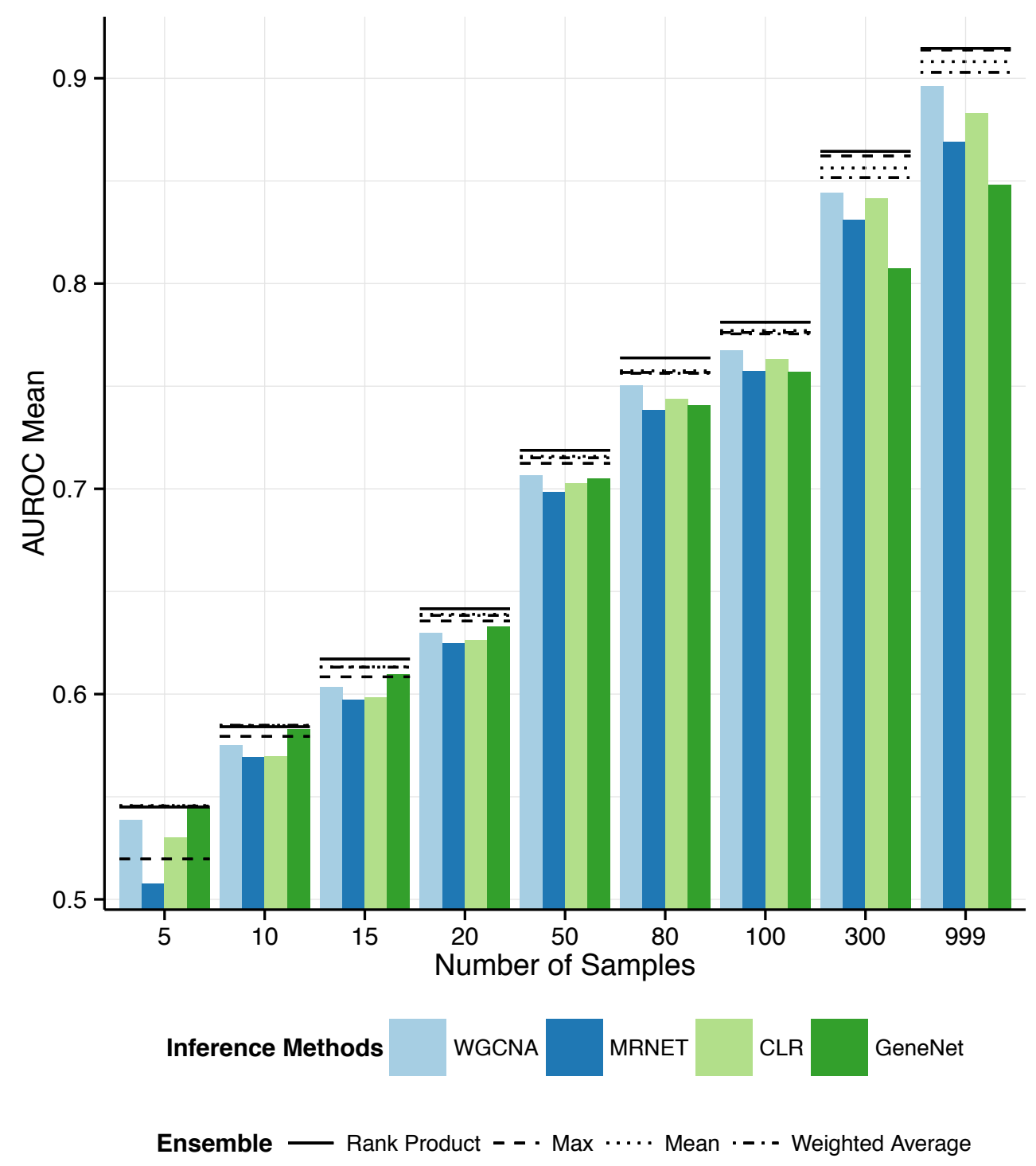

Figura $17-A U R O C$ para as redes inferidas para diferentes tamanhos de conjuntos de dados. Cada valor representa a média $A U R O C$ para os métodos de inferência obtidos a partir de 5 tamanhos de rede diferentes (em termos de número de arestas). As linhas horizontais acima das barras mostram o valor de $A U R O C$ para os comitês.

com valores de $0.125,0.230$ e 0.285 , e WGCNA com os menores valores para $A U P R$ $0.125,0.192$ e 0.222 .

Os valores de $A U P R$ obtidos pelos métodos de inferência para conjuntos de dados menores apresentam variação apenas para redes reconstruídas usando 50 e 80 amostras. Os valores de $A U P R$ do método WGCNA para 50 e 80 amostras foram, respectivamente, 0.078 e 0.110 , do método MRNET foram 0.067 e 0.104 , do CLR foram 0.078 e 0.119 , e do GeneNet foram 0.073 e 0.120 . 


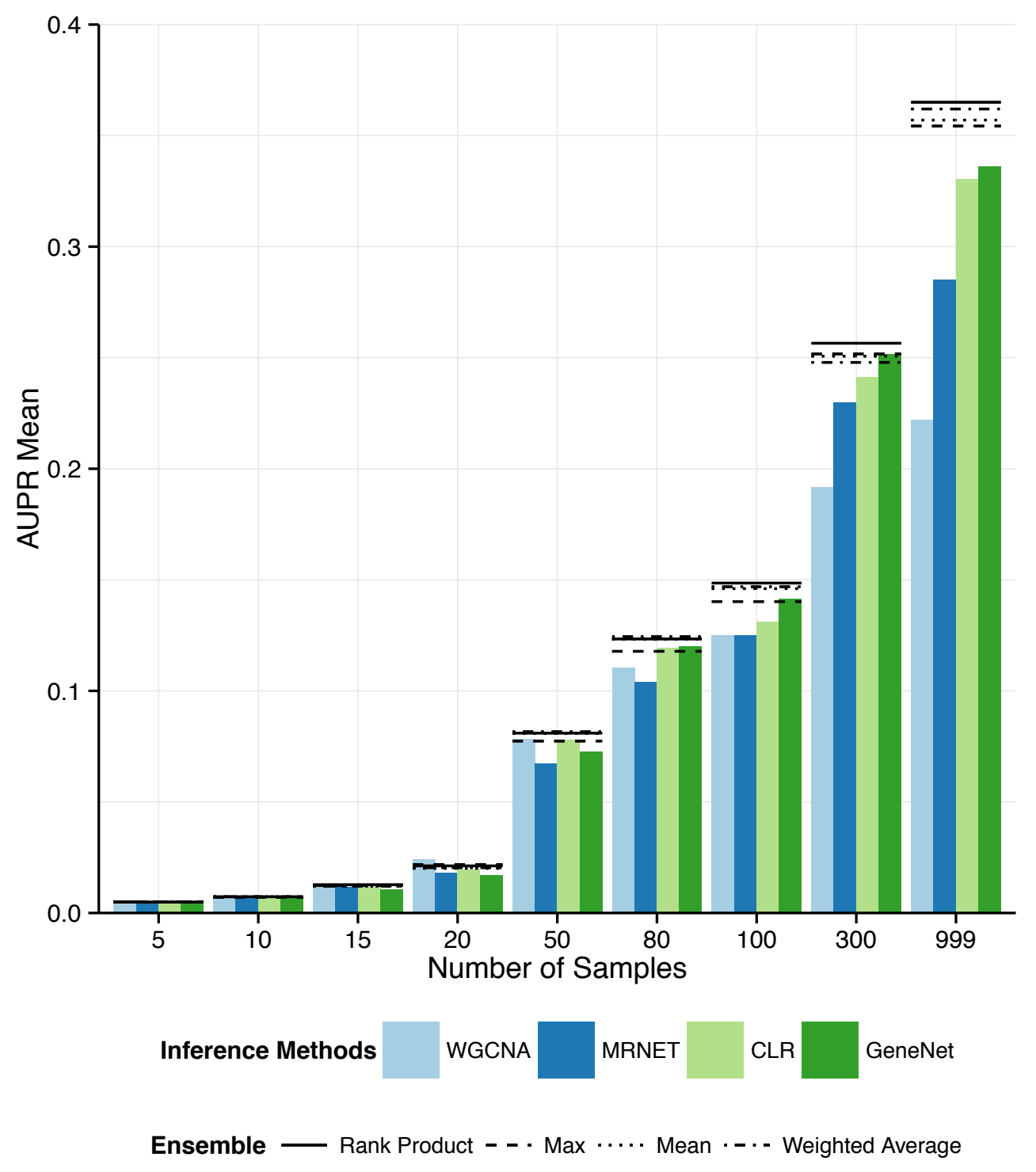

Figura $18-A U P R$ para as redes inferidas para diferentes conjuntos de dados. Cada valor representa a média $A U P R$ para os métodos de inferência obtidos a partir de 5 tamanhos de rede diferentes (em termos de número de arestas). As linhas horizontais acima das barras mostram o valor de $A U P R$ para os comitês.

Enquanto o método WGCNA obteve o melhor desempenho em termos de $A U R O C$, GeneNet apresentou melhores valores de $A U P R$ na maioria das situações. Isto significa que WGCNA apresentou melhor desempenho global (ou seja, considerando o equilíbrio entre TP e TN) do que GeneNet. Por outro lado, GeneNet recuperou corretamente mais interações positivas (considerando TP) do que WGCNA. Isto é importante porque, como redes de genes são esparsas (isto é, o número de zeros é muito maior do que o número de uns no padrão ouro), é preferível recuperar mais verdadeiros positivos, 
mesmo em detrimento da obtenção de um pouco mais de falsos positivos (DAVIS; GOADRICH, 2006).

Conforme discutido a seguir, essa diferença significa que a combinação dos métodos de inferência pode resultar em melhores redes. As Figuras 17 e 18 também mostram as pontuações $A U R O C$ e $A U P R$ obtidas pelas técnicas de comitês consideradas. Em geral, todas as técnicas de comitês desempenham melhor do que qualquer método individual, resultando em melhores resultados em termos de $A U R O C$ e $A U P R$ para redes inferidas a partir de conjuntos de dados com amostras de tamanho 100, $300 \mathrm{e}$ 999. O algoritmo Classificação pelo Produto resultou nos melhores valores de $A U R O C$ $0.781,0.864$ e 0.914 , e $A U P R 0.149,0.257$ e 0.365 , para conjunto de dados contendo 100, 300 e 999, amostras respectivamente.

Os comitês também obtiveram melhor desempenho para conjuntos de dados com número reduzido de amostras. Os valores de $A U R O C$ obtidos pelo algoritmo Classificação pelo Produto para redes inferidas com 5, 10, 15, 20, 50 e 80 amostras, foram, respectivamente: $0.545,0.584,0.617,0.642,0.719$ e 0.764 . Por sua vez, os valores de $A U P R$ obtidos pelo algoritmo Classificação pelo Produto foram $0.005,0.007,0.013$, $0.021,0.081$ e 0.123 . Os valores de $A U R O C$ obtidos pela Regra da Média Ponderada para estas redes foram $0.546,0.585,0.613,0.638,0.715$ e 0.756 , enquanto $A U P R$ eram exatamente os mesmos daqueles obtidos pelo algoritmo Classificação pelo Produto. Para conjuntos de dados contendo 15 ou menos amostras, nota-se que $A U R O C$ aumentou ligeiramente usando comitês e que $A U P R$ é quase o mesmo para todos os comitês e métodos individuais. No geral, quando o número de amostras é maior, a diferença entre os desempenhos de abordagens comitês e métodos individuais tende a aumentar.

Ao contrário de outros estudos, os métodos de inferência individuais e de comitê de especialistas também foram avaliados ao serem aplicados em conjuntos de dados com uma quantidade reduzida de amostras e grande quantidade de genes, a fim de imitar cenários mais realistas. Os resultados sugerem que técnicas de comitê de especialistas podem melhorar a precisão das GRNs inferidas nesta situação. No entanto, não há uma melhoria substancial na precisão ao se aplicar as técnicas de comitê de especialistas em redes inferidas a partir de conjuntos de dados com 15 ou menos amostras. Sugerese que os métodos aqui descritos sejam aplicados em conjuntos de dados que contêm pelo menos 20 amostras, uma vez que a melhoria obtida através da sua aplicação fica mais evidente para conjuntos com maior quantidade de amostras.

O critério de avaliação utilizado no desafio DREAM5 leva em conta que os métodos de inferência geram arestas dirigidas, e os melhores desempenhos obtidos pelos participantes da competição utilizam tanto dados de expressão como dados de fenótipos 
(VIGNES et al., 2011). Por um lado, os métodos de inferência que produzem redes com arestas dirigidas oferecem redes com níveis de informação diferentes do que os métodos apresentados neste estudo, pois arestas dirigidas podem indicar relações de causalidade. Por outro lado, relações de causalidade são difíceis de serem inferidas, exigindo mais amostras de dados (amostras preferencialmente temporais) e outras fontes de dados, para além dos perfis de expressão gênica. Além disso, os métodos de inferência avaliados aqui são de fácil acesso e uso. Mesmo produzindo redes com menos informação, os resultados ainda são valiosos, visto que pesquisadores podem explorar diferentes limiares a fim de encontrar agrupamentos de genes que sejam interessantes. 



\section{CONCLUSÕES E TRABALHOS FUTUROS}

Nesta dissertação foi realizada a avaliação comparativa de métodos na inferência de redes de regulação gênica a partir de dados de expressão gênica. Esses métodos foram escolhidos pela sua popularidade e por terem pacotes de software disponíveis. Nós também realizamos a comparação de quatro técnicas de comitês de especialistas para agregar as redes inferidas: Regra do Máximo, Regra da Média e Regra da Média Ponderada e Classificação pelo Produto.

Os experimentos foram conduzidos utilizando os conjuntos de dados in silico fornecidos pelo desafio DREAM5 e também com um conjunto modificado para que ficassem com poucas amostras.

A avaliação realizada indica que os métodos individuais mostram resultados diferentes dependendo da métrica de avaliação aplicada, com WGCNA e GeneNet desempenhando melhor nos testes realizados. Ao agregar os métodos de inferência descobriu-se que os resultados de um comitê de especialistas é mais preciso do que os métodos individuais na maioria dos casos, corroborando estudos anteriores (ZHONG et al., 2014; MENDOZA; BAZZAN, 2012; MARBACH et al., 2010; MARBACH et al., 2012). Além disso, o algoritmo Classificação pelo Produto desempenhou melhor do que os outros comitês de especialistas.

Pesquisas futuras podem ser realizadas para investigar o uso de técnicas de comitê de especialistas mais complexas na inferência de redes gênicas. Outras combinações de métodos de inferência, incluindo métodos que constroem redes de genes representadas como grafos dirigidos, poderiam levar a GRNs mais precisas. Algoritmos de comitê de especialistas mais complexos também podem ser aplicados para a inferência incremental de conjuntos de dados, que gradualmente se tornam disponíveis, e para a integração de diferentes fontes de dados. Outra ideia interessante para ser explorada é variar não somente o número de amostras, mas também o número de genes.

Finalmente, o desenvolvimento de aplicações de software usando os conceitos desenvolvidos neste trabalho são essenciais para o desenvolvimento deste campo de pesquisa. Como muitos pesquisadores da área de genômica não possuem conhecimentos em programação e técnicas computacionais, um sistema integrativo que aplique as técnicas discutidas aqui poderia colaborar no avanço de suas pesquisas. 



\section{REFERÊNCIAS}

ALAKWAA, F. M. Modeling of Gene Regulatory Networks: A Literature Review. Journal of Computational Systems Biology, Annex Publishers, v. 1, n. 1, p. 8, 2014.

ALBERTS, B.; JOHNSON, A.; LEWIS, J.; RAFF, M.; ROBERTS, K.; WALTER, P. Biologia Molecular da Célula. [S.I.]: Artmed, 2010. 1396 p. ISBN 9788536320663.

BRAZHNIK, P.; FUENTE, A. de la; MENDES, P. Gene Networks: How to put the Function in Genomics. TRENDS in Biotechnology, Elsevier, v. 20, n. 11, p. 467-472, 11 2002. ISSN 01677799.

BUTTE, A. J.; KOHANE, I. S. Mutual Information Relevance Networks: Functional Genomic Clustering Using Pairwise Entropy Measurements. In: Pacific Symposium on Biocomputing. [S.I.: s.n.], 2000. v. 5, p. 418-429.

CARTER, S. L.; BRECHBÜHLER, C. M.; GRIFFIN, M.; BOND, A. T. Gene co-expression network topology provides a framework for molecular characterization of cellular state. Bioinformatics, Oxford University Press, Oxford, UK, v. 20, n. 14, p. 2242-2250, 92004. ISSN 1367-4803.

CHAI, L. E.; LOH, S. K.; LOW, S. T.; MOHAMAD, M. S.; DERIS, S.; ZAKARIA, Z. A Review on the Computational Approaches for Gene Regulatory Network Construction. Computers in Biology and Medicine, v. 48, p. 55-65, 5 2014. ISSN 1879-0534.

CRICK, F. et al. Central Dogma of Molecular Biology. Nature, Nature Publishing Group, v. 227, n. 5258 , p. 561-563, 1970.

DAVIS, J.; GOADRICH, M. The Relationship Between Precision-Recall and ROC Curves. In: ACM. New York, NY, USA: ACM Press, 2006. p. 233-240. ISBN 1595933832.

D'HAESELEER, P.; LIANG, S.; SOMOGYI, R. Genetic network inference: from co-expression clustering to reverse engineering. v. 16, n. 8, p. 707-726, 2000.

FACHINI, A. R.; MARTINS, J. D. C.; COSTA, A. H. R. Using Ensemble Combiners to Improve Gene Network Inference. In: IJCAI. Buenos Aires, Argentina, 2015. p. 17-23.

FAITH, J. J.; HAYETE, B.; THADEN, J. T.; MOGNO, I.; WIERZBOWSKI, J.; COTTAREL, G.; KASIF, S.; COLLINS, J. J.; GARDNER, T. S. Large-scale mapping and validation of escherichia coli transcriptional regulation from a compendium of expression profiles. PLoS biology, Public Library of Science, v. 5, n. 1, p. e8, 2007.

FILKOV, V. Identifying Gene Regulatory Networks from Gene Expression Data. Handbook of Computational Molecular Biology, CRC Press, p. 1-30, 2005.

FRIEDMAN, N.; LINIAL, M.; NACHMAN, I.; PE'ER, D. Using Bayesian Networks to Analyze Expression Data. Journal of Computational Biology, Mary Ann Liebert, Inc., v. 7, n. 3-4, p. 601-20, 1 2000. ISSN 1066-5277. 
GARDNER, T. S.; FAITH, J. J. Reverse-engineering Transcription Control Networks. Physics of Life Reviews, Elsevier, v. 2, n. 1, p. 65-88, 3 2005. ISSN 1571-0645.

HACHE, H. Computational Analysis of Gene Regulatory Networks. 173 p. Tese (Doutorado) - Humboldt-Universität zu Berlin, 2009.

HACHE, H.; LEHRACH, H.; HERWIG, R. Reverse Engineering of Gene Regulatory Networks: A Comparative Study. EURASIP Journal on Bioinformatics and Systems Biology, Hindawi Publishing Corp., New York, NY, USA, v. 2009, p. 8, 1 2009. ISSN 1687-4145.

HECKER, M.; LAMBECK, S.; TOEPFER, S. Gene Regulatory Network Inference: Data Integration in Dynamic Models - A Review. Biosystems, v. 96, n. 1, p. 86-103, 42009. ISSN 1872-8324.

IANCU, O. D.; KAWANE, S.; BOTTOMLY, D.; SEARLES, R.; HITZEMANN, R.; MCWEENEY, S. Utilizing RNA-Seq Data for De Novo Coexpression Network Inference. Bioinformatics, Oxford University Press, v. 28, n. 12, p. 1592-1597, 6 2012. ISSN 1367-4811.

JEONG, H.; TOMBOR, B.; ALBERT, R.; OLTVAI, Z. N.; BARABÁSI, A. L. The Large-Scale Organization of Metabolic Networks. Nature, Nature Publishing Group, n. 6804, p. 651-654, out. ISSN 0028-0836.

JONES, N. C.; PEVZNER, P. A. An Introduction to Bioinformatics Algorithms. Cambridge, MA, USA: MIT Press, 2004.

KADARMIDEEN, H. N.; WATSON-HAIGH, N. S. Building Gene Co-expression Networks Using Transcriptomics Data for Systems Biology Investigations: Comparison of Methods Using Microarray Data. Bioinformation, Biomedical Informatics Publishing Group, v. 8, n. 18, p. $855,2012$.

KAUFFMAN, S. Gene Regulation Networks: A Theory For Their Global Structure and Behaviors. Current Topics in Developmental Biology, Elsevier, v. 6, p. 145-182, 1971.

LÄHDESMÄKI, H.; SHMULEVICH, I.; YLI-HARJA, O. On Learning Gene Regulatory Networks Under the Boolean Network Model. Machine Learning, Springer Berlin Heidelberg, v. 52, n. 1-2, p. 147-167, 2003.

LANGFELDER, P.; HORVATH, S. WGCNA: An R Package for Weighted Correlation Network Analysis. BMC Bioinformatics, BioMed Central Ltd, v. 9, n. 1, p. 559, 2008.

LESK, A. M. Introduction to Bioinformatics. Oxford, UK: Oxford University Press, 2014. 255 p. ISBN 978-0-19-965156-6.

LIANG, S.; FUHRMAN, S.; SOMOGYI, R. Reveal, A General Reverse Engineering Algorithm for Inference of Genetic Network Architectures. In: Pacific Symposium on Biocomputing. [S.I.: s.n.], 1998. v. 3, n. 3, p. 18-29.

LIU, B.; FUENTE, A. de L.; HOESCHELE, I. Gene network inference via structural equation modeling in genetical genomics experiments. Genetics, Genetics Soc America, v. 178, n. 3, p. 1763-1776, 2008. 
LIU, Z.-P. Reverse engineering of genome-wide gene regulatory networks from gene expression data. Current Genomics, Bentham Science Publishers, v. 16, n. 1, p. 3-22, 2015.

LO, L.-Y.; WONG, M.-L.; LEE, K.-H.; LEUNG, K.-S. Large Causal Gene Regulatory Network Inference by Decomposition into Subnetworks. International Journal of Bioscience, Biochemistry and Bioinformatics, v. 5, n. 3, p. 175-183, 2015. ISSN 20103638. Disponível em: <http://www.ijbbb.org/show-57-750-1.html>.

LOPES, F. M. Redes Complexas de Expressão Gênica: Síntese, Identificação, Análise e Aplicações. 136 p. Tese (Doutorado) - Universidade de São Paulo, 2011.

LOPES, F. M.; JR, R. M. C.; COSTA, L. D. F. Gene expression complex networks: synthesis, identification, and analysis. Journal of Computational Biology, Mary Ann Liebert, Inc. 140 Huguenot Street, 3rd Floor New Rochelle, NY 10801 USA, v. 18, n. 10, p. 1353-1367, 2011.

LOPES, F. M.; MARTINS, D. C.; BARRERA, J.; CESAR, R. M. A feature selection technique for inference of graphs from their known topological properties: Revealing scale-free gene regulatory networks. Information Sciences, v. 272, p. 1-15, 2014. ISSN 00200255. Disponível em: <http://linkinghub.elsevier.com/retrieve/pii/ S0020025514002023>.

MACLIN, R.; OPITZ, D. W. Popular ensemble methods: An empirical study. CoRR, abs/1106.0257, 2011. Disponível em: <http://arxiv.org/abs/1106.0257>.

MADHAMSHETTIWAR, P. B.; MAETSCHKE, S. R.; DAVIS, M. J.; REVERTER, A.; RAGAN, M. A. Gene Regulatory Network Inference: Evaluation and Application to Ovarian Cancer Allows the Prioritization of Drug Targets. Genome medicine, v. 4, n. 5, p. 41,1 2012. ISSN 1756-994X.

MARBACH, D.; COSTELLO, J. C.; KüFFNER, R.; VEGA, N. M.; PRILL, R. J.; CAMACHO, D. M.; ALLISON, K. R.; CONSORTIUM, T. D.; KELLIS, M.; COLLINS, J. J.; STOLOVITZKY, G. Wisdom of Crowds for Robust Gene Network inference. Nature, Nature Publishing Group, v. 9, n. 8, p. 796-804, 8 2012. ISSN 1548-7105.

MARBACH, D.; PRILL, R. J.; SCHAFFTER, T.; MATTIUSSI, C.; FLOREANO, D.; STOLOVITZKY, G. Revealing Strengths and Weaknesses of Methods for Gene Network Inference. Proceedings of the National Academy of Sciences of the United States of America, v. 107, n. 14, p. 6286-91, 4 2010. ISSN 1091-6490.

MARBACH, D.; SCHAFFTER, T.; MATTIUSSI, C.; FLOREANO, D. Generating Realistic In Silico Gene Networks for Performance Assessment of Reverse Engineering Methods . Journal of Computational Biology, v. 16, n. 2, p. 229-239, 2 2009. ISSN 1557-8666.

MENDOZA, M. R. Exploring Ensemble Learning Techniques to Optimize the Reverse Engineering of Gene Regulatory Networks. 189 p. Tese (Doutorado) - Universidade Federal do Rio Grande do Sul, 2014. 
MENDOZA, M. R.; BAZZAN, A. L. C. On the Ensemble Prediction of Gene Regulatory Networks: A Comparative Study. Neural Networks (SBRN), 2012 Brazilian Symposium on Neural Networks, IEEE, p. 55-60, 10 2012. ISSN 1522-4899.

METZ, J. Interpretação de Clusters Gerados por Algoritmos de Clustering Hierárquico. 136 p. Dissertação (Mestrado) - Universidade de São Paulo, 2006.

MEYER, P. E.; KONTOS, K.; LAFITTE, F.; BONTEMPI, G. Information-theoretic inference of large transcriptional regulatory networks. EURASIP journal on bioinformatics and systems biology, Hindawi Publishing Corporation, v. 2007, 2007.

NEEDHAM, C. J.; BRADFORD, J. R.; BULPITT, A. J.; WESTHEAD, D. R. A Primer on Learning in Bayesian Networks for Computational Biology. PLOS Computational Biology, Public Library of Science, v. 3, n. 8, p. 129, 8 2007. ISSN 1553-7358.

PINNA, A.; SORANZO, N.; HOESCHELE, I.; FUENTE, A. de la. Simulating Systems Genetics Data with SysGenSIM. Bioinformatics, Oxford University Press, v. 27, n. 17, p. 2459-2462, 2011.

POLIKAR, R. Ensemble based systems in decision making. Circuits and systems magazine, IEEE, IEEE, v. 6, n. 3, p. 21-45, 2006.

SCHÄFER, J.; STRIMMER, K. An Empirical Bayes Approach to Inferring Large-scale Gene Association Networks. Bioinformatics, Oxford University Press, v. 21, n. 6, p. 754-764, 2005.

SHARAN, R.; ULITSKY, I.; SHAMIR, R. Network-based Prediction of Protein Function. Molecular Systems Biology, Wiley Online Library, v. 3, n. 1, 2007.

SHMULEVICH, I.; DOUGHERTY, E. R.; KIM, S.; ZHANG, W. Probabilistic boolean networks: a rule-based uncertainty model for gene regulatory networks. Bioinformatics, v. 18, n. 2, p. 261-274, 2002.

SOINOV, L.; KRESTYANINOVA, M.; BRAZMA, A. Towards reconstruction of gene networks from expression data by supervised learning. Genome biology, v. 4, n. 1, p. R6, 2003. ISSN 1465-6906.

SOMEREN, E. P. van; WESSELS, L. F. A.; BACKER, E.; REINDERS, M. J. T. Genetic Network Modeling. Journal of Computational Biology, v. 3, n. 4, p. 507-525, 2002.

VIGNES, M.; VANDEL, J.; ALLOUCHE, D.; RAMADAN-ALBAN, N.; CIERCOAYROLLES, C.; SCHIEX, T.; MANGIN, B.; GIVRY de S. Gene Regulatory Network Reconstruction Using Bayesian Networks, the Dantzig Selector, the Lasso and their Meta-analysis. PIoS ONE, Public Library of Science, v. 6, n. 12, p. e29165, 12011. ISSN 1932-6203.

WANG, Y. X. R.; HAIYANHUANG. Review on Statistical Methods for Gene Network Reconstruction using Expression Data. Journal of Theoretical Biology, v. 362, p. 53-61, 4 2014. ISSN 1095-8541. 
WATSON, J. D.; CRICK, F. H. C. Molecular structure of nucleic acids. Nature, Nature Publishing Group, n. 4356, p. 737-738.

WHALEN, S.; PANDEY, G. A comparative analysis of ensemble classifiers: Case studies in genomics. Proceedings - IEEE International Conference on Data Mining, ICDM, p. 807-816, 2013. ISSN 15504786.

XIAO, Y. A Tutorial on Analysis and Simulation of Boolean Gene Regulatory Network Models. Current Genomics, Bentham Science Publishers, v. 10, n. 7, p. 511, 2009.

YU, J.; SMITH, V. A.; WANG, P. P.; HARTEMINK, A. J.; JARVIS, E. D. Advances to Bayesian Network Inference for Generating Causal Networks from Observational Biological Data. Bioinformatics, Oxford University Press, v. 20, n. 18, p. 3594-3603, 12 2004. ISSN 1367-4803.

ZHANG, B.; HORVATH, S. A General Framework for Weighted Gene Co-expression Network Analysis. Statistical Applications in Genetics and Molecular Biology, v. 4, n. 1, p. 45, 2005.

ZHONG, R.; ALLEN, J. D.; XIAO, G.; XIE, Y. Ensemble-based Network Aggregation Improves the Accuracy of Gene Network Reconstruction. PloS one, Public Library of Science, v. 9, n. 11, p. 10, 1 2014. ISSN 1932-6203. Disponível em: $<$ http://dx.plos.org/10.1371/journal.pone.0106319>. 